Bartın Üniversitesi

Eğitim Fakültesi Dergisi

Cilt 6, Sayı 3, s. 1264-1292, Ekim 2017

BARTIN - TÜRKIYE

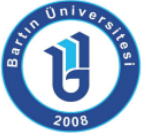

ISSN: 1308-7171
Bartin University

Journal of Faculty of Education

Volume 6, Issue 3, p. 1264-1292, October 2017

BARTIN - TURKEY

\title{
Pedagojik Alan Bilgisi Bağlamında Öğretmen Adaylarının Kesirlerle Ilgili Kavram Yanılgılarını Giderme Yeterliklerinin Farklı Değişkenlere Göre İncelenmesi
}

Hayal YAVUZ MUMCU, Yrd. Doç. Dr., Ordu Üniversitesi, hayalym52@gmail.com

ORCID: http://orcid.org/0000-0002-6720-509X

\begin{abstract}
Öz: Bu araştırmanın amacı öğretmen adaylarının, kesirlerle ilgili olarak öğrencilerde görülmesi muhtemel kavram yanılgılarını gidermeye yönelik yeterlik durumlarını belirleyerek, bu yeterlikleri farklı değişkenlere göre incelemektir. Bu kapsamda ayrıca öğretmen adaylarının söz konusu yanılgıları gidermeye yönelik tercih ettikleri öğretim yöntemleri de araştırılmıştır. Araştırma karma desende yürütülmüştür. Çalışma grubunu bir devlet üniversitesinin ilköğretim matematik öğretmenliği lisans programının son sınıfına devam etmekte olan 52 öğretmen adayı oluşturmaktadır. Çalışmada veri toplama aracı olarak araştırmacı tarafından geliştirilmiş olan ve iki bölümden oluşan Kavram Yanılgıları Giderme Formu (KYGF) kullanılmıştır. Verilerin analizi dört aşamada gerçekleştirilmiştir. Bu süreçte iki bölümden oluşan Puanlama Ölçeği (PÖ) kullanılmıştır. Araştırma sonucunda öğretmen adaylarının kesirlerde görülen kavram yanılgılarını gidermek amacıyla çoğunlukla model kullanma yöntemini tercih ettikleri ve genel olarak geçerli yöntemler önerdikleri fakat bu yöntemleri söz konusu duruma uygun olarak kullanma noktasında yetersiz kaldıkları görülmüştür. Ayrıca Matematik Eğitiminde Kavram Yanılgıları seçmeli dersini alma-almama, mezun olunan okul türü ve genel akademik not ortalaması değişkenlerine göre öğretmen adaylarının kavram yanılgıları giderme yeterlikleri arasında anlamlı ilişkiler/farklılıklar gözlenmemiştir.
\end{abstract}

Anahtar Kelimeler: pedagojik alan bilgisi, kavram yanılgısı, kesir, öğretmen adayları

\section{Examination of Pre-Service Teachers' Ability to Eliminate Misconceptions about Fractions in terms of Pedagogical Content Knowledge According to Different Variables}

\begin{abstract}
The aim of this study is to determine the pre-service teachers' competencies to eliminate possible misconceptions about fractions and to examine these competencies according to different variables. The teaching methods preferred by the prospective teachers have also been investigated. The study has been conducted on the mixed method. The study group is composed of 52 teacher candidates who are senior students of a state university elementary mathematics education program. Eliminating Misconceptions Form was used as data collection tool in the study. The analysis of the data was carried out in four stages. Scoring Scale was used in this process. As a result of the research, it was seen that the teacher candidates mostly preferred the method of using a model in order to eliminate the misconceptions. They generally propose valid methods but they are found to be inadequate to use these methods. Furthermore, there were no significant relationships/differences between the competencies according to variables of taking (or not) elective course of Misconceptions in Mathematics Education, school type and general academic average.
\end{abstract}

Key Words: pedagogical content knowledge, misconception, fractions, pre-service teachers 


\section{GíRiş}

Matematik eğitiminin niteliğin artırılmasında etkili birçok faktör olmakla birlikte, bunlardan en önemlisi hiç kuşkusuz öğretmen eğitimidir. Bir ülkede uygulanan eğitim politikaları ne kadar düzgün işlerse işlesin, öğretim ortamları gerekli tüm fiziksel ve teknolojik donanımlara ne kadar sahip olursa olsun, eğer matematik sınıflarında nitelikli öğretmenleriniz yoksa eğitim süreci sonunda ulaşacağınız nokta muhtemelen beklenenin altında olacaktır. Bununla birlikte, kötü işleyen bir eğitim politikası veya fiziksel ve teknolojik imkânların kısıtlılı̆ı gibi olumsuz faktörlerin söz konusu olduğu öğretim ortamlarında ise, nitelikli öğretmenlerin yürüteceği etkili öğretim süreçleri ile birlikte beklenenin üstünde sonuçlar elde edilebilir.

Öğretmen eğitiminde dikkat edilmesi gereken hususlar söz konusu olduğunda, alan yazında son yıllarda oldukça önem kazanmış ve ilgili çalışmaların sayısı günden güne artmakta olan Pedagojik Alan Bilgisi (PAB) kavramı ön plana çıkmaktadır. PAB ilk olarak Shulman (1986)'ın $A B D$ 'de eğitim üzerine yapılan reform hareketlerini, öğretimi olduğundan daha basit ele alarak öğretim süreçlerinde yaşanan zorlukları yeteri kadar ortaya koymadıkları noktasında eleştirerek ortaya çıkardığı özel bir kavramdır. Shulman (1986) bir öğretmende bulunması gereken üç tür bilgiden söz etmektedir. Bunlar: (a) konu alan bilgisi, (b) pedagojik alan bilgisi ve (c) müfredat bilgisi'dir. Konu alanı bilgisi, öğretmenin alanındaki kavram, olgular, alanın yapısı hakkındaki bilgisi ile bu kavram ve olguların hangi durumlarda geçerliliğinin savunulabileceği bilgisini kapsamaktadır. Müfredat bilgisi öğretim müfredatları ve bunlarla ilişkili kaynakların nasıl kullanılacağının yanında konu ve kavramların farklı yıllarda nasıl ele alındığı ve diğer ders ve öğrenme alanlarıyla ilişkisini içeren bilgi türü olarak tanımlanabilir (Işıksal-Bostan ve Osmanoğlu, 2016). PAB ise Shulman (1986) tarafından, bir konunun/kavramın bireyler tarafından anlaşılabilmesi için gerekli olan en güçlü temsil, gösterim, benzetim, örnek ve açıklamaların neler olabileceğine yönelik sahip olunan bilgi türü olarak tanımlanmaktadır. Bunun yanında bazı özel konu veya kavramların öğretimini zorlaştıran ve kolaylaştıran faktörlerin bilgisi PAB içerisinde kabul edilmektedir. Burada sözü edilen faktörler, farklı yaş ve birikimdeki öğrencilerin ilgili kavram veya konuya ilişkin sahip oldukları ön öğrenmeleridir. Eğer bu öğrenmeler kavram yanılgıları içeriyorsa, bu yanılgıları giderecek biçimde öğrenme süreçlerini tekrar düzenleyebilmek için gerekli olan strateji bilgisi yine PAB içinde yer almaktadır. Ball vd. (2008), Shulman tarafından ortaya atılmış PAB modelini, matematik eğitimi persektifinden ele alarak yorumlamış ve bu bağlamda $P A B^{\prime} n i$ oluşturan üç tür bilgiden söz etmişlerdir. Bunlar Alan Öğretimi Bilgisi, Alana iliş̧kin Öğrenci Bilgisi ile Alan ve Müfredat Bilgisi'dir. Alan Öğretimi Bilgisi (AÖB), özel olarak matematik eğitimi söz konusu olduğunda, matematiğin nasıl öğretileceği ile ilgili olan bilgi türüdür. Buradaki nasıl sorusunun cevabı öğretim süreçlerinde kullanılan yöntem ve teknikleri içermektedir. Alana illişkin Öğrenci Bilgisi (AiÖB) ise öğrencilerin ön öğrenmeleri ve bunların olası sonuçlarını tahmin edebilmeyle ilgili bir kavramdır. Dolayısıyla burada öğrenci ihtiyaçları ön plana çıkmaktadır. Öğretmenlerin, öğrencilerinin belli bir matematik konusunu nasıl anlayabileceklerini bilmesi, karmaşık bulabilecekleri noktaları tahmin edebilmesi, öğrencilerde var olabilecek kavram yanılgılarının farkında olması ve öğretim planını hazırlarken tüm bunları göz önünde bulundurması söz konusu bilginin varlı̆ııla mümkün olabilmektedir. Alan ve program bilgisi ise uygulanan öğretim programı hakkında bilgi sahibi olmayı içermektedir. Dolayısıyla özellikle matematik eğitimi söz konusu olduğunda, öğrencilerin kavram yanılgılarının anlaşılması ve giderilmesi noktasında $P A B^{\prime} ı$ önemli bir rolü olduğu görülmektedir.

Öğrencilerin temel eğitim sürecinde karşılaştıkları en soyut kavram kesir kavramıdır (Newstead ve Murray, 1998) ve kesirlerin öğrenimi öğrenciler açısından matematik öğrenme sürecindeki en büyük engellerden biridir (Behr vd., 1993). Yapılan çalışmalar (Alacacı, 2010; Booker, 1998; Davis, 2003; Hart, 1987; Hasemann, 1981; Işık ve Kar, 2012; Okur ve ÇakmakGürel, 2016; Erbilgin vd., 2017; Thompson, 1993) öğrencilerin kesir kavramıyla ilgili farklı tür hata 
ve yanılgılara sahip olduklarını göstermektedir ve söz konusu yanılgıların nedenleri farklı çalışmalarda farklı yaklaşımlarla ele alınmaktadır. Bu yaklaşımlardan biri kesir kavramının kendisinden kaynaklanan nedenler, diğeri ise öğretim sürecinin niteliğinden kaynaklanan nedenler olarak ifade edilebilir.

Kesirlerin öğrenciler tarafından tam olarak anlaşılamaması ve kavramla ilgili öğrencilerin hata ve yanılgılara düşmesinin nedenini, kavramın kendi yapısı ile ilişkilendiren araştırmalardan Bigalke ve Hasemann (1978) ile Padberg (1978) çalışmalarında söz konusu nedenleri; kesirlerin günlük yaşamda doğal sayılar kadar kullanılmaması, kesirleri anlatmanın doğal sayılar kadar kolay olmaması, kesirlerin yazılı formunun doğal sayılardan daha karmaşık olması, kesirleri sayı doğrusunda göstermenin ve sıralamanın kolay olmaması, kesir işlemlerinin doğal sayılardan çok daha karmaşık olan birçok kurala sahip olması olarak ifade etmektedirler. Ayrıca bu araştırmacılar, kesir işlemlerinin zamanından önce öğrenilmesinin, bu işlemlerin ezbere ve düşüncesizce kullanılmasına neden olacağını ifade etmektedirler. Hasemann (1981) ile Mack $(1990,1995)$ ise söz konusu nedenleri kesirlerin yazılı formunun karmaşık olması, kesir aritmetiğinin birçok kuralının olması, kesrin sembolik dili ile anlamı arasındaki ilişkinin kurulamaması olarak ifade etmişlerdir. Dickson vd. (1993) kesirlerde öğrenci güçlüklerinin nedenlerinden biri olarak kesrin birçok anlamı içinde barındırıyor olmasını göstermekte, Leinhardt ve Smith (1984) de benzer olarak, söz konusu güçlüklerin nedeni olarak kavramlar ve gösterimler arasındaki karmaşık ilişkileri göstermektedirler. Hart (1981) ise bu zorluğun nedeni olarak işlemsel kuralları işaret etmektedir.

Kesirlerin genel olarak sahip olduğu farklı anlamlar parça-bütün, ölçme, bölme, işlemci ve oran olarak ifade edilebilir (Van De Walle vd., 2004). Parça-bütün anlamı, bir bütünün birbirine eş olan parçalarından bir veya birkaç tanesinin bütünün tamamına oranı biçiminde ifadelendirilebilir ve bu sözel ifade aslında günlük yaşamda kullandığımız tüm kesir anlamları ile ilişkilidir. Sınıfın 3/5'ü sinemaya gitti ifadesinde kullanılan $3 / 5$ kesri, bütün, sınıf mevcudu olarak düşünüldüğünde ve 5 parça olarak alındığında, bunun 3 parçası olarak, bir oranı ifade etmektedir ve kesrin parça-bütün anlamını taşımaktadır. $1 / 2 \mathrm{~km}$ yolumuz kaldı ifadesinde kullanılan $1 / 2$ kesri, bütün $1 \mathrm{~km}$ olarak alındığında ve 2 parça olarak düşünüldüğünde, bunun 1 parçası olarak bir oranı ifade etmektedir ve kesrin ölçme anlamını taşımaktadır. 20 metrekarenin 4/5'i boyandı ifadesinde kullanılan 4/5 kesri, bütün 20 metrekare olarak düşünüldüğünde ve 5 parça olarak alındığında bunun 4 parçası olarak bir oranı ifade etmektedir ve kesrin işlemci anlamını taşımaktadır. 3 pizza 4 çocuk tarafından paylaşıldığında 1 çocuğun payına düşen pizza miktarını ifade eden $3 / 4$ kesri, bütün 4 parça olarak düşünüldüğünde, bunun 3 parçası olarak bir oranı ifade etmektedir ve kesrin bölüm anlamını taşımaktadır. Son olarak sınıftaki gözlük takan öğrencilerin gözlük takmayan öğrencilere oranı 1/1'tür ifadesindeki $1 / 4$ kesri bir oranı ifade ettiğinden ötürü kesrin oran anlamını taşımaktadır. Dolayısıyla kesrin tüm anlamlarında bir parça-bütün olgusuna bağlı oran anlamının var olduğu görülmektedir. Charalambous ve Pitta-Pantazi (2005) de benzer şekilde kesirlerin parça-bütün anlamlarının diğer dört anlamı ile ilişkili olduğunu, bu ilişkinin işlemci ve oran anlamlarında daha kuvvetli iken; ölçü ve bölüm anlamlarında diğer iki anlama oranla daha az olduğunu ifade etmektedir. Bu görüşe paralel olarak Karaağaç ve Köse (2015) parça-bütün kavramının tam olarak anlaşılmamasının kesir kavramının tam olarak öğrenilememesine sebep olduğunu ifade etmektedir. 


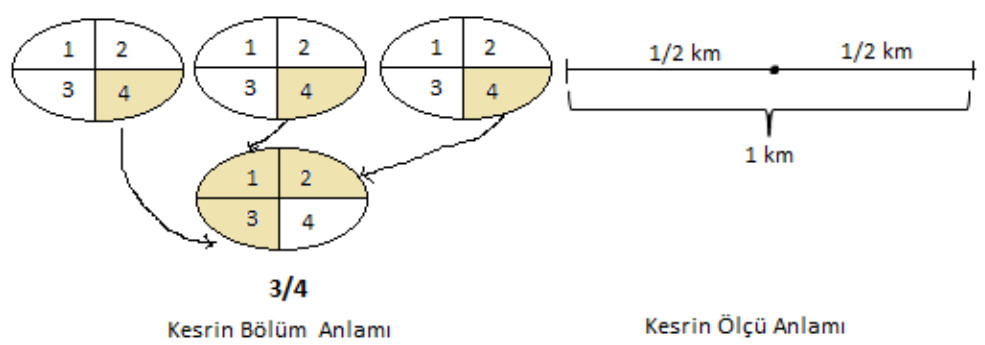

Şekil 1. Kesrin bölüm ve ölçü anlamları

Kesirlerle ilgili olarak yapılan öğrenci hata ve yanılgılarını, öğretim sürecinin niteliği ile ilişkilendiren çalışmalardan Reys vd. (1998) ile Van De Walle vd. (2004), söz konusu hata ve yanılgıların birçoğunun nedeni olarak kesir öğretimine özensiz yaklaşımları göstermektedirler. Benzer şekilde Bezuk ve Bieck (1993) sınıfta öğrencilerin deneyimlerine dayanmadan ve temel kavramsal alt yapı geliştirilmeden kesirlerin soyut sembollerle gösterimine erken ve aceleci bir geçişin kavram yanılgılarına yol açtığını ifade etmektedir. Aksu (1997) ile Mok vd. (2008) ise kesir kavramı tam olarak öğrenilmesine yeterli zaman ayrılmadan kesirlerle işlemlerin öğretimine geçilmesini, öğrencilerin yaşadıkları hata ve yanılgıların önemli bir nedeni olarak göstermektedir. Zira Hanson (1995), öğrencilerin kesirlerle ilgili yaşadıkları sorunların temelinde büyük ölçüde formülleri ve algoritmaları ezberleme çabalarının yattığını ileri sürmektedir. Pantziara ve Philippou (2011) ise kavramsal anlamaya yönelik etkinliklere yeterince yer verilmemesini kesirlerle ilgili hata ve yanılgıların nedenleri arasında saymaktadır.

Soylu ve Soylu (2005), öğretim süreci içerisinde öğretmenlerin, öğrencilerinin yaşadıkları öğrenme güçlüklerini ve sahip oldukları kavram yanılgılarını belirleyerek, buna göre bir öğretim stratejisi belirledikleri takdirde, kesirlerde kavramsal düzeyde öğrenmenin gerçekleşmesinin mümkün olduğunu ifade etmektedirler. Van-Steenbrugge vd. (2014) ise, öğretmen eğitiminin, öğrencilerin kesirler konusundaki eksik anlamalarının giderilmesinde kilit bir role sahip olduğunu söylemektedirler. Öğretilecek konu veya kavram ne kadar zor ve karmaşık olursa olsun, kavramın ne zaman ve nasıl öğretileceği kararını veren tek kişi olan öğretmenin, kavramların anlamlı olarak öğrenilmesindeki etkisi hiç kuşkusuz tartışılmaz büyüklüktedir (Leinhardt ve Smith, 1985). Moss ve Case (1999), matematik eğitiminde yapılan son zamanlardaki araştırmalarda; öğrencilerin herhangi bir kavram yanılgısı oluşturmalarını engelleyecek bir yolla öğretim yapmanın imkânsız olduğunun belirtildiğini ifade etmekte lakin bununla birlikte öğretmenler söz konusu yanılgıları açığa çıkarmak için özel bir çaba harcamadıkça da bu yanılgıların gizli kalacağını söylemektedirler. Bu nedenle, aynı çalışmada, kavram yanılgılarını tartışan ve açığa çıkaran öğretim stillerinin kullanımı ile birlikte kavram yanılgılarının sınırlandırılabileceği ifade edilmektedir. Bu bağlamda öğretmenlerin PAB'lerinin niteliğinin belirlenerek zenginleştirilmesine yönelik atılacak adımların ve yapılacak farklı çalışmaların oldukça önemli olduğu düşünülmektedir. Zira Shulman (1986, s.10) öğrencilerin öğretilen kavramlarla ilgili olarak ne tür kavram yanılgılarına sahip olabileceği ve bu yanılgıların nasıl giderilebileceğine ilişkin bilgi türlerinin, bir öğretmenin sahip olması gereken en önemli pedagojik bilgi türlerinden olduğu ifade etmektedir.

Kesirlerle ilgili olarak alan yazında farklı çalışmalar olmakla birlikte, öğretmen adaylarının, muhtemel kavram yanılgılarının çözümüne yönelik olarak PAB'larını inceleyen çalışmaların oldukça sınırlı olduğu görülmektedir. Bu noktadan hareketle bu araştırmanın problemi ve alt problemleri aşağıdaki gibi ifade edilebilir.

\subsection{Problem Durumu}

Bu araştırmanın problemi: Öğretmen adaylarının kesir kavramına yönelik kavram yanılgılarını giderme bağlamında pedagojik alan bilgilerini kullanma yeterlikleri nasıldır ve söz konusu yeterlikler arasında farklı değişkenlere göre anlamlı farklılıklar/ilişkiler görülmekte midir? 
şeklinde ifade edilebilir. Çalışma sonuçları ile alan yazındaki söz konusu boşluğun giderilmesine katkı sağlanacağı düşünülmektedir. Çalışma kapsamında aşă̆ıdaki alt problemler yanıtlanmaya çalışılmıştır.

1. Öğretmen adaylarının kesirlerle ilgili kavram yanılgılarını gidermek amacıyla kullandıkları yöntemler nelerdir?

2. Öğretmen adaylarının kesirlerle ilgili kavram yanılgılarını gidermek amacıyla kullandıkları yöntemler, kavram yanılgısının türüne göre nasıl değişmektedir?

3. Öğretmen adaylarının kesirlerle ilgili kavram yanılgılarını giderme yeterlikleri nasıldır ve kullanılan yöntemlere göre nasıl değişmektedir?

4. Öğretmen adaylarının kesirlerle ilgili kavram yanılgılarını giderme yeterlikleri mezun olunan okul türü ve Matematik Eğitiminde Kavram Yanılgıları (MEKY) seçmeli dersini alma/almama değişkenlerine göre anlamlı derecede farklılaşmakta mıdır?

5. Öğretmen adaylarının kesirlerle ilgili kavram yanılgılarını giderme yeterlikleri ile genel akademik not ortalamaları (GANO) arasında anlamlı bir ilişki var mıdır?

\section{YÖNTEM}

Bu araştırma bir karma yöntem araştırmasıdır. Creswell ve Plano Clark (2007) karma yöntem araştırmasını, nitel ve nicel yöntemlerle veri toplama, analiz etme ve bütünleştirmeye olanak veren araştırma olarak tanımlamaktadır. Mason (2006) sosyal deneyimlerin ve gerçeklerin çok boyutlu olduğunu ve bunları tek bir boyutuyla incelememiz halinde ortaya çıkan algının eksik olacağını vurgulamaktadır. Karma yöntem araştırması yaklaşımı bu ilkeye dayanarak farklı yöntemlerin aynı araştırmada bir arada kullanılması gerektiğini savunmaktadır (Yıldııı ve Şimşek, 2013; s.352). Bu araştırmada öğretmen adaylarının kavram yanılgılarını giderme düzeylerini belirleyerek ilgili alt problemlere yanıtlayabilmek amacıyla nicel ve nitel yöntemler bir arada kullanılmıştır. Bu nedenle araştırma karma desende yürütülmüştür.

Araştırmanın deseni karma yöntem desenlerinden olan açımlayıcı desendir. Açımlayıcı desen, iki aşamadan oluşan bir yaklaşımla planlanmaktadır. Önce araştırmanın nitel bölümü gerçekleştirilmekte, bu bölümden elde edilen veriler doğrultusunda nicel bölüme geçiş yapılmaktadır (Yıldırım ve Şimşek, 2013; s.358). Bu araştırmada öğrencilerin kavram yanılgılarını giderme durumlarının veri analizine uygun hale getirilmesinde nitel yöntemlerden yararlanılarak içerik analizi tekniği kullanılmış, araştırmanın devamında ise nicel yöntemlerle çalışıldığı için bu desenin kullanımı uygun görülmüştür.

\section{1. Çalışma Grubu}

Araştırmanın çalışma grubunu bir devlet üniversitesinin Illköğretim Matematik Öğretmenliği programına devam etmekte olan 52 son sınıf öğrencisi oluşturmaktadır. Çalışma grubunun belirlenmesinde amaçlı örneklem yöntemlerinden kolay ulaşılabilir durum örneklemesi kullanılmıştır. Amaçlı örneklem seçimindeki mantık, araştırmanın daha derinlemesine yapılabilmesi için bilgi zengini durumları seçmektir (Patton, 2014; s.230). Bu araştırmada özel olarak matematik öğretmen adaylarından son sınıfta öğrenim görmekte olanlar seçildiğinden bu yöntemin kullanımı uygun görülmüştür.

Kolay ulaşılabilir durum örneklemesinin kullanımında ise amaç, araştırmaya hız, maliyet ve zaman açısından avantajlar sağlamaktır (Yıldırım ve Şimşek, 2013, s.141). Zira bu yöntemde araştırmacı yakın ve erişilmesi kolay olan durumlar üzerinde çalışmaktadır. Bu yöntem eğitim araştırmaları için geçerlik ve güvenirliği düşürmesi nedeniyle çok fazla tercih edilmemekle birlikte, bu araştırmanın yapısına uygun olması nedeniyle tercih edilmiştir. Az sayıda örneklem üzerinde derinlemesine çalışılmış olan ve nitel yönü ağır basan bu araştırma için söz konusu 
yöntemin uygun olduğu görülmüş ve araştırmanın geçerlik ve güvenirliği için ilerleyen bölümlerde ifade edilmiş olan tedbirler alınmıştır. Araştırmada yer alan katılımcılara ilişkin demografik bilgiler Tablo 1'de verilmektedir.

Tablo 1

Çalışma Grubunda Yer Alan Öğretmenlere ilişkin Demografik Bilgiler

\begin{tabular}{lll}
\hline Demografik Bilgiler & & Frekans \\
\hline \multirow{3}{*}{ Mezun Olunan Okul Türü } & Fen Lisesi & 1 \\
& Anadolu/Anadolu İmam Hatip Lisesi & 22 \\
& Anadolu Öğretmen Lisesi & 14 \\
& Düz Lise & 14 \\
& Meslek Lisesi & 1 \\
\hline \multirow{3}{*}{ Genel Akademik Not Ortalaması } & $3,1-4$ & 6 \\
& $2,51-3$ & 30 \\
\hline MEKY Dersini Alma/Almama Durumu & $2-2,50$ & 16 \\
& Alanlar & 24 \\
\hline Toplam & Almayanlar & 28 \\
\hline
\end{tabular}

MEKY: Matematik Eğitiminde Kavram Yanılgıları

\subsection{Veri Toplama Araçları}

Öğretmen adaylarının kesirler konusundaki kavram yanılgılarını giderme düzeylerinin belirlenmesine yönelik olarak araştırmacı tarafından Kavram Yanılgıları Giderme Formu (KYGF) hazırlanmıştır. Söz konusu form iki ayrı bölümden oluşmaktadır. Birinci bölümde öğretmen adaylarının demografik bilgilerini sorgulayan üç adet soru yer almaktadır. Bu sorular öğretmen adaylarının mezun oldukları okul türünü, uygulamanın yapıldığı tarih itibariyle genel akademik not ortalamaları (GANO)'nı ve Matematik Eğitiminde Kavram Yanılgıları seçmeli dersini alıp almadıklarını belirlemeye yönelik olarak hazırlanmıştır. Formun ikinci bölümünde ise sekiz adet açık uçlu soru yer almaktadır ve her bir soru kesirler konusu ile ilgili olarak sahip olunabilecek farklı tür yanılgıları içermektedir. Bu sorularda öğretmen adaylarına, söz konusu yanılgıları gidermek için geliştirecekleri çözüm yollarının neler olabileceği sorulmaktadır. KYGF'de yer alan soruların hazırlanmasında Alacacı (2010) çalışmasından yararlanılarak kesirlerle ilgili olarak ifade edilen kavram yanılgısı türleri referans alınmıştır. Bunlar (a) Kesirlerde Miktarın Referans Alınan Bütüne Bağlı Olması (RAB), (b) Kesirlerde Kısımlara Ayırma (KA), (c) Kesirlerin Karşılaştırılması (KK), (d) Bileşik Kesirlerde Birimin Belirlenememesi (BKB), (e) Hatalı Kesir Toplamı (HKT), (f) Çarpmanın Kesirlere Etkisi (ÇKE), (g) Bölmenin Kesirlere Etkisi (BKE) ve (h) Kesrin Yarısının Elde Edilişi (KYE) olarak ifade edilebilir. KYGF'nin ikinci bölümünde öncelikli olarak öğretmen adaylarına mevcut sorularla ilgili bazı açıklamalar yapılmaktadır. Bu açıklamalar kapsamında; KYGF'de yer alan sorulara verilen tüm yanıtların ortaokul 6-7. sınıf seviyesindeki öğrencilere uygun olarak hazırlanması ve yanıtların mümkün olduğunca açık ve anlaşılır olarak ifade edilmesi gerektiği, öğretmen adaylarının tüm sorulara yanıt vermek zorunda olmadıkları ve istedikleri soruları boş bırakabilecekleri ifade edilmiştir. Veri toplama aracının uygulanmasında herhangi bir süre sınırlandırması yapılmamış, öğretmen adaylarının kimliklerinin gizli tutulması suretiyle mevcut soruları samimiyetle doğru yanıtlamaları sağlanmaya çalışıımıştır.

KYGF'nin geçerliği için alanında uzman iki öğretim üyesinin görüşlerinden ve pilot çalışmalardan yararlanılmıştır. Zira Kabapınar (2003) kavram yanılgıları ile ilgili olarak açık uçlu yapıda hazırlanan ve nitel yönü ağır basan ölçeklerin geçerliğinin uzman görüşleri ve pilot çalışmalarla sağlandığını ifade etmektedir. Alan uzmanlarının görüşlerinden yararlanılarak hazırlanan sorular öncelikle farklı bir üniversitede öğrenim görmekte olan ve 24 kişiden oluşan benzer bir öğrenci grubuna uygulanmıştır. Bu uygulama sonrasında öğrencilere KYGF ile ilgili olarak anlamakta güçlük çektikleri noktalar olup olmadığı sorularak bu öğrencilerden bazıları ile 
bireysel görüşmeler yapılmıştır. Pilot çalışma sonrasında sorularda açık olmayan ya da farklı algılamalara yol açabilen ifadeler öğrenci görüşleri doğrultusunda düzeltilmiştir. Bu aşamadan sonra pilot çalışmada yer alan öğrencilerle aynı sınıfta öğrenim görmekte olan benzer bir öğrenci grubu ile ikinci bir pilot uygulama gerçekleştirilerek KYGF' de yer alan soruların uygulanabilirliği test edilmiştir.

\subsection{Verilerin Analizi}

Araştırmanın yapısına uygun olarak veri analizi süreci dört adımda gerçekleştirilmiştir. Bunlar (a) KYGF'ye verilen yanıtların değerlendirilmesinde kullanılacak puanlama ölçeğinin (PÖ) oluşturulması, (b) yanıtların kodlanması ve puanlanması, (c) yanıtların kodları kullanılarak araştırmanın bir, iki ve üçüncü alt problemlerine yönelik nitel analizlerin gerçekleştirilmesi, (d) yanıtların puanları kullanılarak araştırmanın dördüncü ve beşinci alt problemine yönelik nicel analizlerin gerçekleştirilmesi olarak ifade edilebilir.

\subsubsection{Puanlama Ölçeği (PÖ)'nin Oluşturulması}

Öğretmen adaylarının KYGF'ye verdikleri yanıtların analizinde kullanılacak olan PÖ’nün oluşturulmasında öncelikle ölçeğin alt boyutlarına karar verilmiştir. Bunun için içerik analizinden yararlanılmış ve öğretmen adaylarının yanıtları, farklı türdeki kavram yanılgılarını gidermek için kullandıkları öğretim yöntemleri ve yanıtların benzer noktaları dikkate alınarak beş tema altında toplanmıştır. Bu temalar Somut Nesne/ Materyal Kullanma (SN/MK), Açıklama Yapma/Soru Sorma (AY/SS), Model Kullanma (MK), Boş (B) ve Diğer (D) olarak ifade edilebilir. Diğer temasında yer alan yanıtlar ilgili temalar dışında kalan geçersiz yanıtlardan oluşmaktadır. Bu temada yer alan yanıtlar söz konusu yanılgıların giderilmesine yönelik herhangi bir öneri içermeyen veya oldukça belirsiz ifadelerden oluşan yanıtlardır. Konuyu baştan anlatırım türündeki yanıtlar da oluşturulan temalar dışında kalması ve açık bir öneri içermemesine bağlı olarak bu tema altında değerlendirilmiştir.

Öğretmen adaylarınınyanıtlarının niteliğinin belirlenmesinde öncelikle öğretmen adaylarının yanıtları KYGF' de yer alan her bir soru için tek tek okunmuş ve benzer nitelikte olanlar gruplandırılmıştır. Her soru için yapılan bu gruplandırmaların neticesinde ortaya çıkan farklı yanıt türlerinin ortak noktaları saptanmaya çalışılmış ve söz konusu yanıt türleri tek bir isim altında toplanmaya, bir başka deyişle yanıtların kodları oluşturulmaya çalışılııştır. Süreç sonunda öğretmen adaylarının tüm sorular için ortak olarak kullandıkları bir yapı belirlenmiştir. Buna göre öğretmen adaylarının söz konusu sorularda ifade edilen yanılgıların çözümüne yönelik olarak verdikleri yanıtların üç farklı türde olduğu görülmüştür. Buna göre birinci türdeki yanıtlar, söz konusu yanılgıyı gidermeye yönelik olarak özel bir öğretim yönteminin ve duruma ilişkin olarak bu yöntemin nasıl kullanılacağının açıkça ifade edildiği yanıtlardır. Bu tür yanıtlarda yer alan uygulama ve etkinlikler, doğru yöntemlerin kullanılışına bağlı olarak geçerli, öğrencilerin sahip oldukları yanılgıların giderilmesi anlamında ise yeterli görülmüştür. Bu nedenle $G / Y$ olarak kodlanmışlardır. İkinci tür yanıtlar, söz konusu yanılgıyı gidermeye yönelik yöntemin doğru olarak ifade edildiği fakat bu yöntemin nasıl uygulanacağına ilişkin açık bir resmin olmadığı yanıtlardır. Bu tür yanıtlar, doğru yöntemin ifade edilişine bağlı olarak kısmen geçerli olarak görülmekle birlikte, öğrencilerin sahip oldukları yanılgıları giderme noktasında yetersiz olarak değerlendirilmişlerdir. Bu nedenle KG/YSZ olarak kodlanmışlardır. Üçüncü türdeki yanıtlar ise söz konusu yanılgıların giderilmesine yönelik açık bir ifade içermeyen veya uygun olmayan yöntemlerin kullanılışını içeren yanıtlardır. Doğru yöntemleri içermemelerine bağlı olarak geçersiz, öğrencilerin yanılgılarını giderme noktasında da yetersiz olarak değerlendirilmiş ve GSZ/YSZ olarak kodlanmışlardır.

Söz konusu yapının oluşturulması sürecinde alanda uzman iki öğretim üyesinin daha fikirlerine başvurularak PÖ’nün içeriğinin belirlenmesi hususunda fikir birliğine varılmaya 
çalışılmıştır. Süreç sonunda KYGF'den elde edilen yanıtların değerlendirilmesi için Tablo 2' de yer alan puanlama ölçeği (PÖ) oluşturulmuştur.

Tablo 2

KYGF'ye Verilen Yanıtları Puanlama Ölçeği

\begin{tabular}{|c|c|c|c|}
\hline Yanıtın Niteliği & $\begin{array}{l}\text { Yanitın } \\
\text { Kodu }\end{array}$ & Açıklama & Puan \\
\hline $\begin{array}{l}\text { Geçerli-Yeterli } \\
\text { Yanıt }\end{array}$ & $G / Y$ & $\begin{array}{l}\text { - Söz konusu yanılgıyı gidermeye yönelik geçerli çözüm } \\
\text { önerilerini eksiksiz olarak içeren yanıtlar }\end{array}$ & 2 \\
\hline $\begin{array}{l}\text { Kısmen Geçerli- } \\
\text { Yetersiz Yanit }\end{array}$ & KG/YSZ & $\begin{array}{l}\text { - Söz konusu yanılgıyı gidermeye yönelik geçerli yöntemi } \\
\text { doğru biçimde ifade edip, yöntemin nasıl kullanılacağının açık } \\
\text { olarak belirtilmediği yanıtlar } \\
\text { - Söz konusu yanılgıyı gidermeye yönelik geçerli yöntemi } \\
\text { doğru biçimde ifade edip, yöntemin doğru kullanımını tam } \\
\text { olarak içermeyen yanıtlar } \\
\text { - Söz konusu yanılgıyı gidermeye yönelik geçerli yöntemin } \\
\text { tüm adımlarını tam olarak içermeyen yanıtlar }\end{array}$ & 1 \\
\hline $\begin{array}{l}\text { Geçersiz- } \\
\text { Yetersiz Yanit }\end{array}$ & GSZ/YSZ & $\begin{array}{l}\text { - Söz konusu yanılgıyı gidermeye yönelik geçerli çözüm } \\
\text { önerilerini açık olarak içermeyen yanıtlar } \\
\text { - Söz konusu yanıgıyı gidermeye yönelik geçersiz çözüm } \\
\text { önerilerini içeren yanıtlar }\end{array}$ & 0 \\
\hline Boş Yanıt & B & $\begin{array}{l}\text { - Boş bırakma } \\
\text { - Bilmiyorum, yorumlayamıyorum şeklinde yanıtlar }\end{array}$ & 0 \\
\hline Diğer & $\mathrm{D}$ & $\begin{array}{l}\text { - Söz konusu yanılgının giderilmesine yönelik bir öneri } \\
\text { içermeyen yanıtlar } \\
\text { - Söz konusu yanılgının giderilmesine yönelik tüm konunun } \\
\text { tekrar anlatılmasının önerildiği yanıtlar }\end{array}$ & 0 \\
\hline
\end{tabular}

\subsubsection{Yanıtların Kodlanması ve Puanlanması}

Kodlama sürecinde araştırmayı yürüten araştırmacı tarafından yapılan kodlama işlemi birkaç kez tekrarlanarak ortaya çıkabilecek farklı türdeki hatalardan arındırılmaya çalışılımıştır. Ayrıca araştırmacı tarafından veri analizi süreci her bir yanıt türü için karşılaştırmalı olarak tekrar tekrar incelenerek veri seti için bir bütünlük oluşturulmaya çalışılmıştır. Araştırmayı yürüten tek bir araştırmacı olmasından ötürü yanıtların kodlanmasında birden fazla uzman görüşünden yararlanılmış ve oluşturulan farklı nitelikteki yanıtların uzman kişilerce tekrar tekrar kodlanması sağlanarak kollayıcılar arasında fikir birliği sağlanana dek görüşmeler yapılmıştır. Görüşlerinden yararlanılan iki öğretim üyesi ve araştırmacı arasındaki uyum yüzdeleri farklı tür yanıtlar için için süreç sonunda Tablo 3'teki şekilde hesaplanmıştır. Bunun için Miles ve Huberman'ın (1994, s. 64) formülü (Güvenirlik = görüş birliği / (görüş birliği + görüş ayrılı̆̆ı)) kullanılmıştır.

Tablo 3

Kodlama Güvenirliğine Yönelik Olarak Yapılan Uyum Yüzdeleri

\begin{tabular}{lll}
\hline Yanit Türleri & Uyum Yüzdesi 1 & Uyum Yüzdesi 2 \\
\hline G/Y & $108 /(108+13)=0,89$ & $106 /(106+15)=0,87$ \\
\hline KG/YSZ & $151 /(151+21)=0,87$ & $155 /(155+17)=0,90$ \\
\hline GSZ/YSZ & $69 /(69+11)=0,86$ & $71 /(71+9)=0,88$ \\
\hline B & $52 /(52+1)=0,98$ & $51 /(51+2)=0,96$ \\
\hline D & $28 /(28+5)=0,84$ & $28 /(28+5)=0,84$ \\
\hline
\end{tabular}

Yanıtların kodlanması sürecinde, KYGF'de yer alan sorular için iki farklı yöntemin birarada kullanımını öneren öğretmen adaylarının yanıtlarının tek bir tema altında altında 
değerlendirilmesine özen gösterilmiştir. Burada amaç, veri analizinde ortaya çıkabilecek belirsiz durumların önüne geçerek, araştırma sonuçlarının yorumlanmasında daha net bir resim elde etmektir. Söz konusu süreçte, öğretmen adayının ağırıklı olarak kullandığı yöntem esas alınmıştır.

\subsubsection{Nitel Analizlerin Gerçekleştirilmesi}

KYGF'ye verilen yanıtların kodlarından yararlanılarak bu bölümde frekans ve yüzde (\%) değerleri kullanılmış ve betimsel analizler gerçekleştirilmiştir. Yapılan betimsel analizler çerçevesinde, öğretmen adaylarııın KYGF için vermiş oldukları yanıtların kodlarının, toplamda ve farklı temalar altında nasıl bir dağılım gösterdiği belirlenmeye çalışılııştır. Yapılan veri analizlerinin sonuçlarının ifade edilmesinde, KYGF'de yer alan her soru için yapılan farklı türdeki kodlamaların daha açık görülmesi ve bu bağlamda çalışmanın geçerliğinin artırılması amacıyla farklı kodlara sahip yanıtlardan direkt alıntılara yer verilmiştir. KYGF' de yer alan sorular, içerdiği kavram yanılgısı türlerine göre sekiz farkıı kategoride ele alınarak değerlendirilmiştir.

\subsubsection{Nicel Analizlerin Gerçekleştirilmesi}

PÖ yardımıyla elde edilen nicel veriler bir istatistik programı kullanılarak analiz edilmiştir. Araştırmada kullanılacak olan değişkenlerin, KYGF puanları ile olan ilişkilerinin analizinde kullanılacak olan test türlerinin belirlenebilmesi amacıyla öncelikle KYGF puan verilerinin normal dağılım gösterip göstermediği Kolmogorov-Smirnov (K-S) testi ile belirlenmiş ve verilerin normal dağııım gösterdiği ( $p=0,153, p>.05)$ sonucu elde edilmiştir. Bundan sonra KYGF puanlarının farklılaşma durumu, MEKY seçmeli dersini alıp almama değişkenine göre parametrik testlerden bağımsız örneklem t-testi ile mezun olunan okul türü değişkenine göre ise yine parametrik testlerden ANOVA testi ile incelenmiştir. Grup varyanslarının homojenliği Levene testi sonuçları ile sağlanmıştır. Öğretmen adaylarının genel akademik not ortalamaları (GANO) ile KYGF puanları arasındaki ilişkinin anlamlılı̆ına yönelik olarak ise korelasyon analizi yapılmıştır.

\section{BULGULAR ve YORUM}

3.1. Öğretmen Adaylarının Kesirlerde Görülen Kavram Yanılgılarını Gidermek Amacıyla Kullandıkları Yöntemlere İlişkin Bulgular

$\mathrm{Bu}$ araştırmada yer alan öğretmen adaylarının, kesirlerle ilgili kavram yanılgılarını giderme noktasında tercih ettikleri yöntemlere ilişkin sayısal veriler Tablo 4'te verilmektedir.

Tablo 4

Öğretmen Adaylarının Yanıtlarının Farklı Tema ve Kategorilere Göre Dağılımı

\begin{tabular}{|c|c|c|c|c|c|c|c|c|c|c|c|c|c|c|}
\hline \multirow[b]{2}{*}{ SK } & \multirow[b]{2}{*}{$G / Y$} & \multicolumn{2}{|c|}{ SN/MK } & \multicolumn{2}{|l|}{ Toplam } & \multicolumn{2}{|c|}{ AY/SS } & \multirow{2}{*}{ Toplam } & \multirow{2}{*}{\multicolumn{2}{|c|}{$\begin{array}{r}\text { MK } \\
\text { G/Y KG/YSZ } \\
\end{array}$}} & \multirow{2}{*}{ GSZ/YSZ } & \multirow{2}{*}{ Toplam } & \multirow[t]{2}{*}{ B } & \multirow[t]{2}{*}{ D } \\
\hline & & KG/YSZ & GSZ/YSZ & & $\mathbf{G} / \mathbf{Y}$ & KG/YSZ & SSZ/YSZ & & & & & & & \\
\hline RAB & 18 & 1 & - & 19 & 1 & 9 & 3 & 13 & 14 & 1 & 1 & 16 & 1 & 3 \\
\hline KA & - & 5 & 3 & 8 & 1 & 21 & 9 & 31 & 4 & 2 & 1 & 7 & 2 & 4 \\
\hline KK & 5 & - & - & 5 & 1 & 6 & 3 & 10 & 28 & 7 & - & 35 & 1 & 1 \\
\hline BKB & - & 1 & - & 1 & 2 & 13 & 11 & 26 & 9 & 3 & 1 & 13 & 11 & 1 \\
\hline BKB & - & 1 & - & 1 & 1 & 10 & 9 & 20 & 10 & 6 & 2 & 18 & 12 & 1 \\
\hline HKT & - & - & 1 & 1 & 0 & 6 & 6 & 12 & 16 & 12 & 4 & 32 & 1 & 6 \\
\hline ÇKE & - & - & - & - & 3 & 12 & 3 & 18 & 9 & 11 & 2 & 22 & 6 & 6 \\
\hline BKE & - & - & 1 & 1 & - & 12 & 6 & 18 & 3 & 8 & 6 & 17 & 12 & 4 \\
\hline KYE & - & 2 & 1 & 3 & - & 13 & 2 & 15 & 6 & 12 & 2 & 20 & 7 & 7 \\
\hline Ort & & & & 4,33 & & & & 18,11 & & & & 20,00 & 5,88 & 3,66 \\
\hline Toplan & 23 & 10 & 6 & & 9 & 100 & 55 & & 99 & 62 & 19 & & 53 & 33 \\
\hline
\end{tabular}

Tablo 4'te yer alan veriler öğretmen adaylarının kesirlerle ilgili kavram yanılgılarını giderme noktasından en çok model kullanma yöntemini tercih ettiklerini göstermektedir. 
Bundan sonra tercih edilen yöntemler ise sırasıyla açıklama yapma/soru sorma ve somut nesne /materyal kullanma olarak ifade edilebilir. Ortalama 20 öğretmen adayı $(\% 38,46)$ kavram yanılgılarını giderme noktasında model kullanmayı tercih ediyorken, 18 öğretmen adayı $(\% 34,61)$ açıklama yapmayı/soru sormayı, 4 öğretmen adayı $(\% 7,69)$ ise somut nesne/materyal kullanmayı tercih etmektedirler. Buradaki sayısal veriler göz önüne alındığında somut nesne/materyal kullanmayı tercih eden öğretmen adaylarının oranının diğer yöntemleri tercih eden öğretmen adaylarına oranla daha az olduğu dikkat çekmektedir. Diğer yöntemlerin tercih edilme oranları ise hemen hemen aynıdır.

Tablo 4, çalışmada ele alınan kavram yanılgılarının türlerine göre ele alınarak yorumlandığında, kesirlerde miktarın referans alınan bütüne bağı olması kategorisinde 19 öğretmen adayının $(\% 36,53)$ somut nesne/materyal kullanma yöntemini, 16 öğretmen adayının $(\% 30,76)$ model kullanmayı ve 13 öğretmen adayının ise (\%25) açıklama yapma/soru sorma yöntemini tercih ettiği görülmektedir. Mevcut sayısal veriler göz önüne alındığında farklı yöntemleri tercih eden öğretmen adaylarının oranları arasında büyük farklılıklar olmadığı dikkat çekicidir. Bu kategoride, farklı yöntemler içerisinde yer alan G/Y, KG/YSZ ve GSZ/YSZ yanıtlar için örnek durumlar Şekil 2' de verilmektedir.

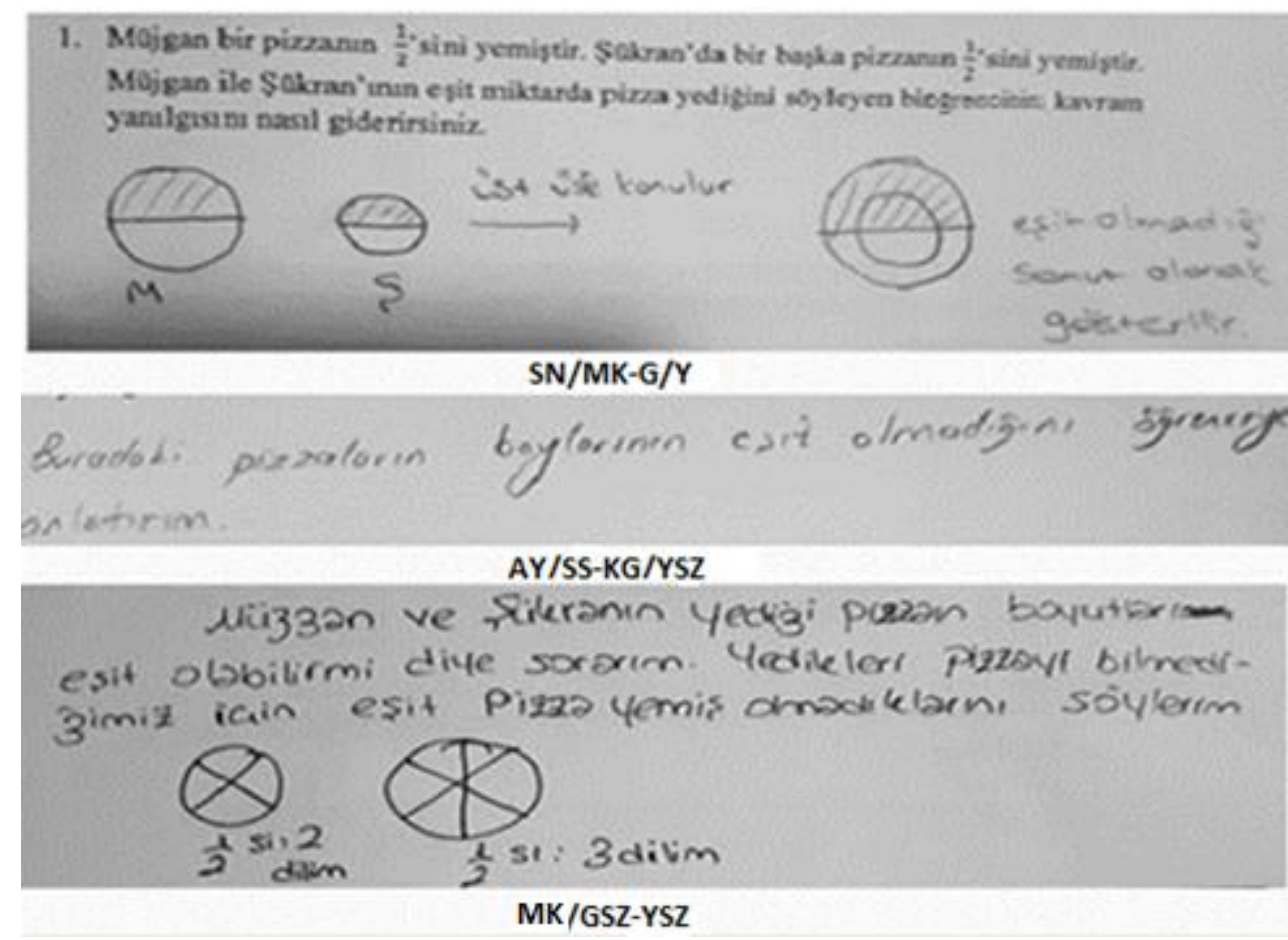

Şekil 2. RAB kategorisindeki farklı tür yanıtlar için örnek durumlar

Şekil 2'de yer alan ilk alıntıda öğretmen adayı, farklı boyutlarda iki pizzanın üst üste konulmasıyla pizzaların $122^{\prime}$ lik kısımlarının eşit olmayacağının öğrenciye gösterilebileceğini ifade etmektedir. Dolayısıyla ilgili yanıt SN/MK teması altında G/Y olarak kodlanmıştır. İkinci alıntıda öğretmen adayı pizzaların boylarının eşit olmadığını öğrenciye anlatırım şeklinde, söz konusu yanılgının nasıl giderileceğine ilişkin çok açık olmayan bir ifade kullanmıştır. Zira burada yapılması gereken, aynı sembollerle gösterilen kesirlerin her zaman aynı büyüklüğü ifade etmeyeceğinin öğrenciye kavratılmasıdır. Bu nedenle söz konusu yanıt AY/SS teması altında KG/YSZ olarak kodlanmıştır. Üçüncü alıntıda ise öğretmen adayının söz konusu durum için uygun olmayan bir model kullanmasından ötürü yanıtı, MK teması altında GSZ-YSZ olarak kodlanmıştır. 
Kesirlerde kısımlara ayırma kategorisinde 31 öğretmen adayının $(\% 59,61)$ açıklama yapma/soru sorma yöntemini, 8 öğretmen adayının $(\% 15,38)$ somut nesne/materyal kullanmayı ve 7 öğretmen adayının ise $(\% 13,46)$ model kullanma yöntemini tercih ettiği görülmektedir. Bu kategoride özellikle açıklama yapma/soru sorma yönteminin diğer yöntemlere nazaran daha fazla tercih edildiği görülmektedir. Diğer yöntemlerin tercih edilme oranları ise hemen hemen aynıdır. Bu kategoride farklı yöntemler içerisinde yer alan G/Y, KG/YSZ ve GSZ/YSZ yanıtlar için örnek durumlar Şekil 3'te verilmektedir.

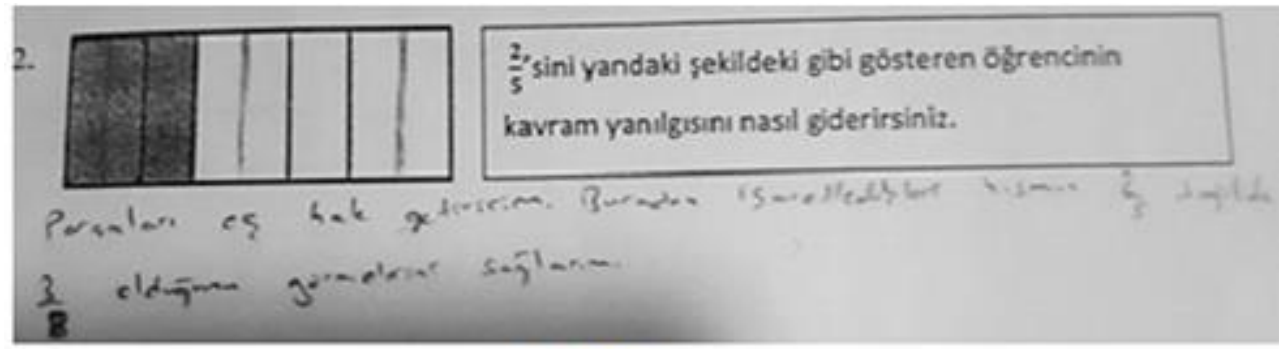

MK /G-Y

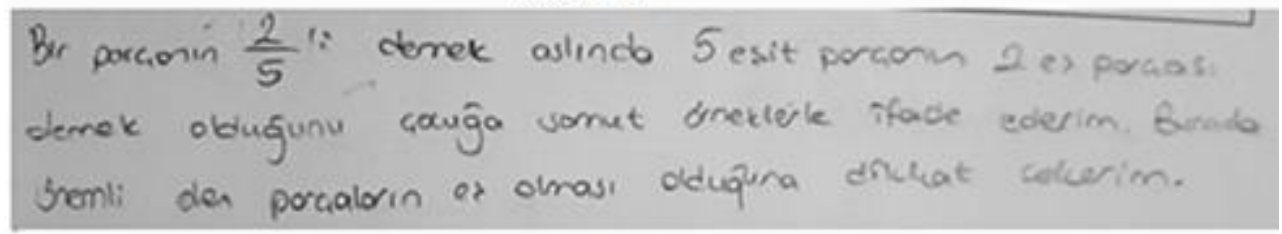

SN/MK-KG/YSZ

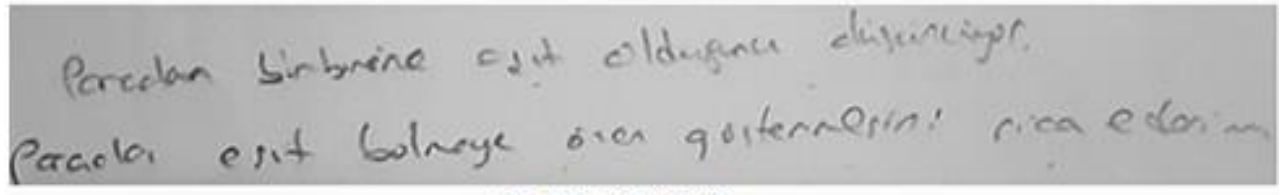

AY/SS-GSZ /YSZ

Şekil 3. KA kategorisindeki farklı tür yanıtlar için örnek durumlar

Şekil 3'te yer alan ilk alıntıda öğretmen adayının, 2/5 kesri için doğru olmayan bir model kullanan öğrencinin, yapmış olduğu hatayı kendisine gösterebilmek amacıyla farklı bir model geliştirdiği görülmektedir. Böylece öğrenci, kesri neden yanlış biçimde göstermiş olduğunu görecek ve hatasının nedenini anlayabilecektir. Dolayısıyla söz konusu yanıt MK teması altında G/Y olarak kodlanmıştır. İkinci alıntıda öğretmen adayı kesrin model ile gösteriminde parçaların eş büyüklükte olması gerektiğini öğrenciye somut örneklerle ifade edeceğini ve bu süreçte parçaların eş olması gerektiğine dikkat çekeceğini söylemekte, fakat bunu nasıl yapacağını tam olarak açıklamamaktadır. Bu nedenle söz konusu yanıt SN/MK teması altında KG-YSZ olarak kodlanmıştır. Üçüncü alıntıda ise rica ederim ifadesinin, öğrencinin söz konusu durumun bir gereklilik olduğunu hissetmesine bir engel teşkil edebileceği düşünülmektedir. Burada öğrenciye sahip olduğu yanılgının çözümüne yönelik herhengi bir müdahalede bulunulmamaktadır. Bu nedenle söz konusu yanıt AY/SS teması altında GSZ/YSZ olarak kodlanmıştır.

Kesirlerin karşılaştırılması kategorisinde 35 öğretmen adayı $(\% 67,30)$ model kullanma yöntemini tercih ederken, $10(\% 19,23)$ öğretmen adayı açıklama yapma/soru sorma, $5(\% 9,61)$ öğretmen adayı ise somut nesne/materyal kullanma yöntemini tercih etmişlerdir. İlgili veriler incelendiğinde özellikle model kullanma yöntemini tercih eden öğretmen adaylarının oranının, diğer yöntemleri tercih eden öğretmen adaylarının oranlarına göre çok daha yüksek olması dikkat çekicidir. Bu kategoride farklı yöntemler içerisinde yer alan G/Y ve KG/YSZ yanıtlar için örnek durumlar Şekil 4'te verilmektedir. Bu kategoride geçersiz yanıt bulunmamaktadır. 


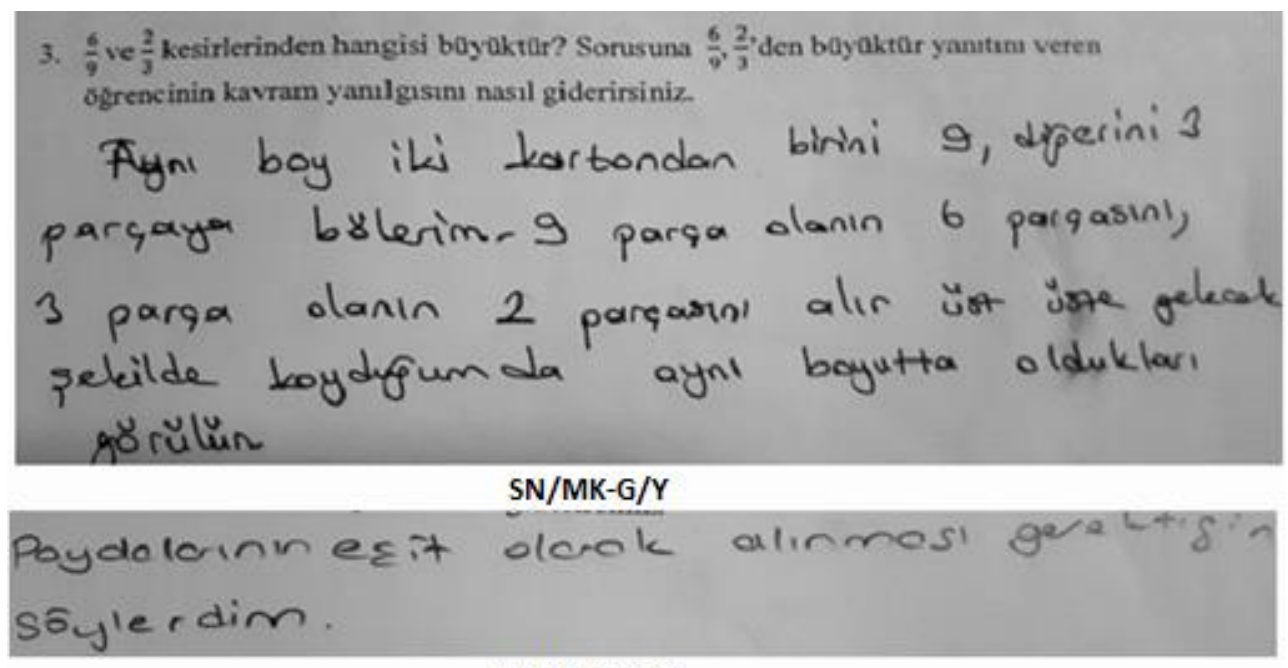

\section{AY/SS-KG/YSZ}

Şekil 4. KK kategorisindeki farklı tür yanıtlar için örnek durumlar

Şekil 4'te yer alan ilk alıntıda öğretmen adayının, kesirlerin karşılaştırılması için somut nesne/materyal kullanma yöntemini uygun olarak kullandığı görülmektedir. Bu nedenle yanıtı SN/MK teması altında G/Y olarak kodlanmıştır. İkinci alıntıda ise öğretmen adayının, kesirlerin karşılaştırılması için paydaların eşit olarak alınması gerektiğini ifade ettiği görülmektedir. Bu ifade doğru olmakla birlikte, öğrencinin kavram yanılgısını çözme noktasında yetersiz kalmaktadır. Bu nedenle ilgili yanıt AY/SS teması altında KG/YSZ olarak kodlanmıştır.

Bileşik kesirlerde birimin belirlenememesi kategorisinde iki farklı soru yer almaktadır. Dolayısıyla burada öğretmen adaylarının her iki soru için vermiş oldukları yanıtlar aynı kategoride değerlendirilmiştir. Bu kategoride yer alan iki soru için açıklama yapma/soru sorma yöntemini tercih etme durumunun diğer yöntemlere göre daha kuvvetli olduğu, bundan sonra ise model kullanma yönteminin tercih edildiği görülmektedir. Somut nesne/materyal kullanma yöntemini ise öğretmen adaylarının genel olarak tercih etmedikleri söylenebilir. Bu kategoride farklı yöntemler içerisinde yer alan $G / Y, K G / Y S Z$ ve GSZ/YSZ yanıtlar için örnek durumlar şekil 5 'teverilmektedir.

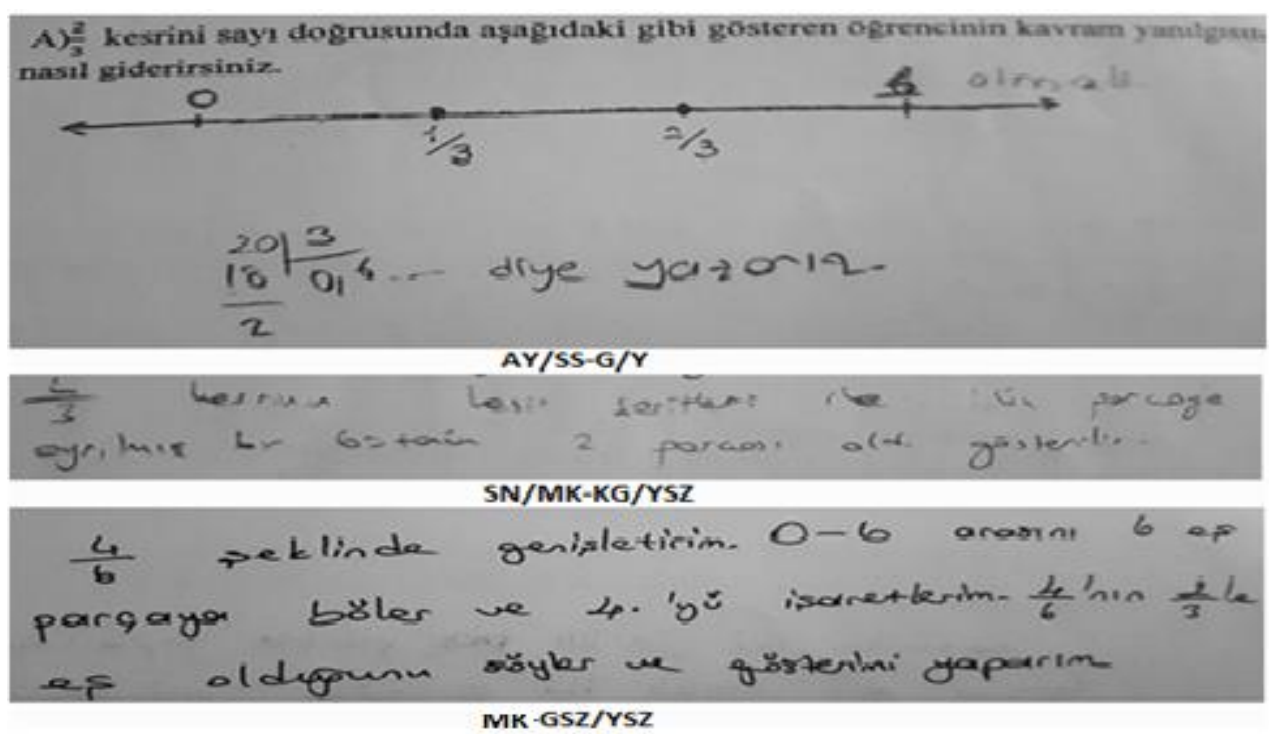

Şekil 5. BKB kategorisindeki farklı tür yanıtlar için örnek durumlar 
Şekil 5'te yer alan ilk alıntıda öğretmen adayının 2/3 kesrinin sayı doğrusu üzerindeki yerinin belirlenmesine yönelik olarak bölme işlemini kullandığı ve bu bilgiden yararlanarak $2 / 3$ kesrini sayı doğrusuna yerleştirdiği görülmektedir. Burada öğretmen adayının, 2/3 kesrinin daha somut olarak anlaşılabilmesi için bir açıklama kullandığı ve bu açıklamayı kullanarak sonuca ulaştığı görülmektedir. Söz konusu yöntem öğrencinin $2 / 3$ kesrinin sayı doğrusu üzerindeki yerini kavraması için yeterli görülmüş ve ilgili yanıt $A Y / S S$ teması altında, $G / Y$ olarak değerlendirilmiş ve kodlanmıştır. İkinci alıntıda öğretmen adayı kesir şeritleri kullanarak $2 / 3$ kesrini, üç parçaya ayrılmış bir bütünün 2 parçası olarak göstereceğini ifade etmektedir. Bu yanıt $2 / 3$ kesrinin materyal yardımı ile gösteriminde geçerli bir niteliğe sahip olmakla birlikte, öğrencinin yanılgısını giderme noktasında yeterli değildir. Zira öğrencinin kullandığı sayı doğrusu modelinde de $2 / 3$ kesri, üç parçaya ayrılmış bir bütünün 2 parçası olarak ifade edilmektedir. Dolayısıyla ilgili yanıt SN/MK teması altında KG/YSZ olarak kodlanmıştır. Üçüncü alıntıda ise öğretmen adayının mevcut soruda öğrencinin kullanmış olduğu sayı doğrusu modelini kullandığı görülmektedir. Bu nedenle ilgili yanıt MK teması altında yer almaktadır. Yanıtın içeriğine bakıldığında ise öğretmen adayının, öğrencinin ifadesini doğru kabul ettiği görülmektedir. Öğretmen adayı, öğrencinin kullandığı sayı doğrusu üzerinde verilen aralığı 6 eş parçaya bölerek 4. adımı 4/6 olarak işaretlemekte ve $2 / 3$ ile $4 / 6$ kesirlerinin sayı doğrusunda aynı noktaya karşılık geldiğini göstermektedir. Yani 4/6 kesrini sayı doğrusu üzerinde gösterirken $[0,1]$ aralığını değil $[0,6]$ aralığını kullanmaktadır. Dolayısıyla öğretmen adayının öğrenci ile aynı yanılgıya sahip olduğu söylenebilir. Bu nedenle ilgili yanıt GSZ/YSZ olarak kodlanmıştır.

Hatalı kesir toplamı kategorisinde 32 öğretmen adayı (\%61,53) model kullanma yöntemini tercih ederken, 12 öğretmen adayı $(\% 23,07)$ açıklama yapma/soru sorma yöntemini, 1 öğretmen adayı $(\% 1,92)$ ise somut nesne/materyal kullanma yöntemini tercih etmiştir. Buradaki veriler model kullanmayı tercih eden öğretmen adaylarının oranının diğer yöntemleri tercih eden öğretmen adaylarına oranla belirgin biçimde daha fazla olduğunu göstermektedir. Öğretmen adaylarının bu kategoride genel olarak somut nesne/materyal kullanma yöntemini tercih etmedikleri söylenebilir. Bu kategoride farklı yöntemler içerisinde yer alan $G / Y, K G / Y S Z$ ve GSZ/YSZ yanıtlar için örnek durumlar Şekil 6'da verilmektedir.

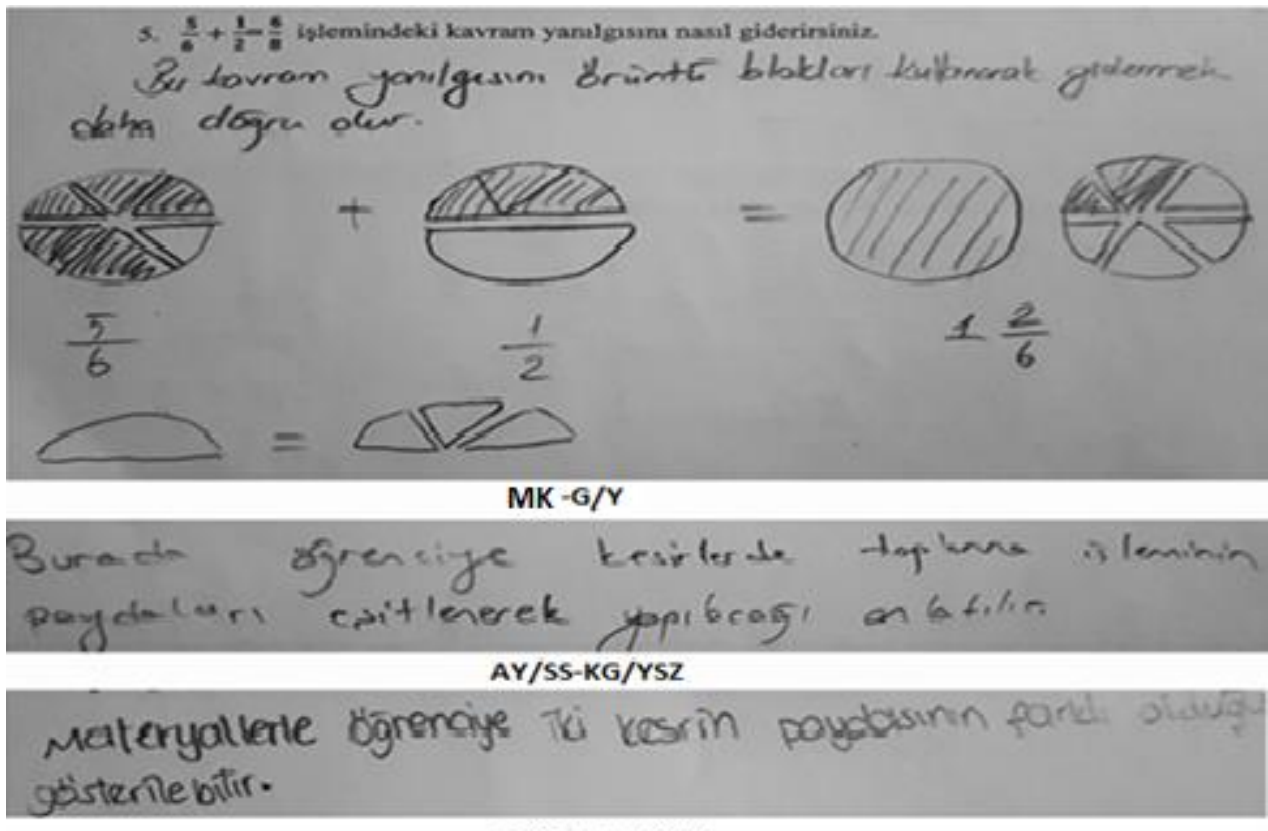

SN/MK-GSZ/YSZ

Şekil 6. HKT kategorisindeki farklı tür yanıtlar için örnek durumlar 
Şekil 6' da yer alan ilk alıntıda öğretmen adayının ilgili toplama işlemini kesir modelleriyle doğru biçimde ifade ettiği görülmektedir. Söz konusu gösterim öğrencinin sahip olduğu yanılgının giderilmesinde yeterli olarak değerlendirilmiştir. Bu nedenle ilgili yanıt MK teması altında G/Y olarak kodlanmıştır. İkinci alıntıda öğretmen adayı kesirlerle toplama işleminin kesirlerin paydaları eşitlenerek yapılacağı şeklinde ezberi bir bilgi (açıklama) vermektedir. Bu bilgi doğru olmakla birlikte öğrencinin sahip olduğu yanılgıyı giderme noktasında yetersizdir. Bu nedenle ilgili yanıt AY/SS teması altında KG/YSZ olarak kodlanmıştır. Üçüncü alıntıda ise öğretmen adayı, öğrenciye materyal kullanarak iki kesrin paydasının farklı olduğunu gösterebileceğini söylemektedir. Burada materyal kullanımının ifade edilen durum için uygun bir yöntem olmadığı görülmekle birlikte, sözü edilen yöntemin kullanılış biçiminin ise öğrencinin yanılgısını giderme noktasında yetersiz olduğu görülmektedir. Bu nedenle ilgili yanıt SN/MK teması altında GSZ/YSZ olarak değerlendirilmiştir ve kodlanmıştır.

Çarpmanın kesirlere etkisi kategorisinde 22 öğretmen adayı $(\% 42,30)$ model kullanma yöntemini tercih ederken, 18 öğretmen adayı $(\% 34,61)$ ise açıklama yapma/soru sorma yöntemini kullanmıştır. Bu kategoride somut nesne/materyal kullanma yöntemini tercih eden öğretmen adayına rastlanmamıştır. illgili sayısal veriler dikkate alındığında bu kategoride model kullanma ve açıklama yapma/soru sorma yöntemini kullanan öğretmen adaylarının oranlarının oldukça yüksek ve birbirine yakın değerler olduğu görülmektedir. Bu kategoride farklı yöntemler içerisinde yer alan G/Y, KG/YSZ ve GSZ/YSZ yanıtlar için örnek durumlar Şekil 7'de verilmektedir.

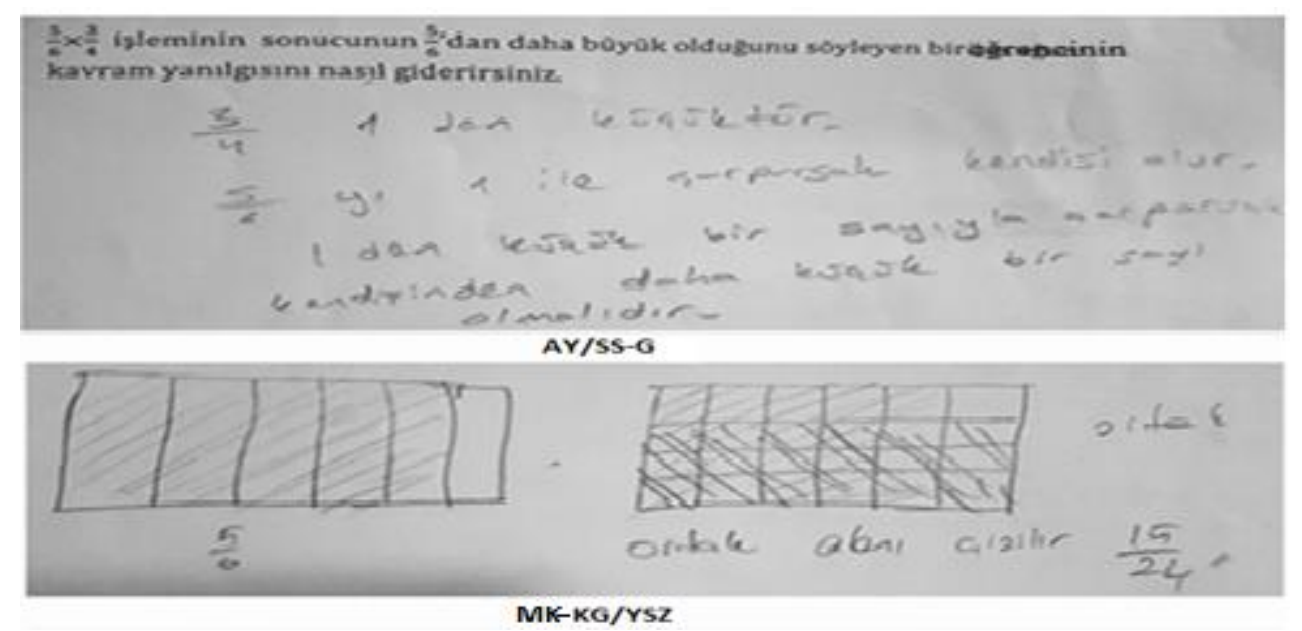

Şekil 7. ÇKE kategorisindeki farklı tür yanıtlar için örnek durumlar

Şekil 7'de yer alan ilk alıntıda öğretmen adayının 3/4 kesri 1'den küçük olduğu için 5/6 ile çarpımının sayının kendisinden (yani 5/6'dan) daha küçük olacağı biçiminde bir açıklama kullandığı görülmektedir. Bu açıklama öğrencinin yanılgısını giderme noktasında yeterli görüldüğü için ilgili yanıt $A Y / S S$ teması altında $G / Y$ olarak değerlendirilmiştir. íkinci alıntıda öğretmen adayı $5 / 6$ ile $3 / 4$ kesirlerinin çarpımına yönelik bir model kullanmıştır. Kullanılan bu model duruma uygun olmakla birlikte, çarpım sonucunun $5 / 6$ 'dan daha küçük olduğu bilgisini içermemesine bağlı olarak kısmen geçerli olarak değerlendirilmiş ve öğrencinin yanılgısını giderme noktasında yetersiz bulunmuştur. Bu nedenle ilgili yanıt MK teması altında KG/YSZ olarak değerlendirilmiştir ve kodlanmıştır.

Bölmenin kesirlere etkisi kategorisinde 18 öğretmen $(\% 34,61)$ adayı açıklama yapma/soru sorma yöntemini tercih ederken, 17 öğretmen adayı $(\% 32,69)$ ise model kullanma yöntemini tercih etmişlerdir. Sadece 1 öğretmen adayı somut nesne/materyal kullanma yöntemini tercih etmiştir. Dolayısıyla söz konusu veriler, öğretmen adaylarının büyük oranda açıklama yapma/soru sorma veya model kullanma yöntemini tercih ettiklerini, somut 
nesne/materyal kullanma yönteminin ise öğretmen adayları tarafından genel olarak tercih edilmediğini göstermektedir. Bu kategoride farklı yöntemler içerisinde yer alan G/Y, KG/YSZ ve GSZ/YSZ yanıtlar için örnek durumlar Şekil 8'de verilmektedir.

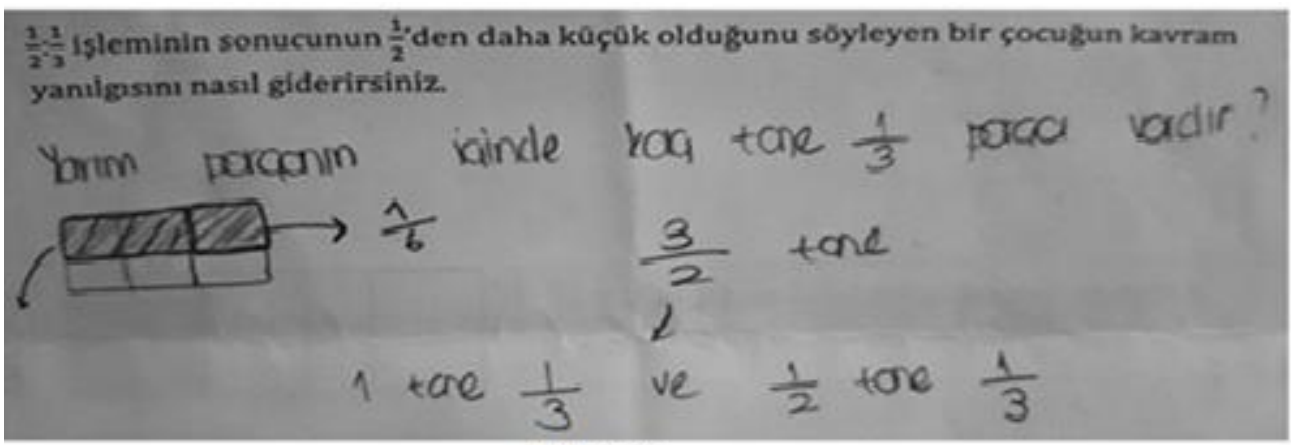

MK-G/Y

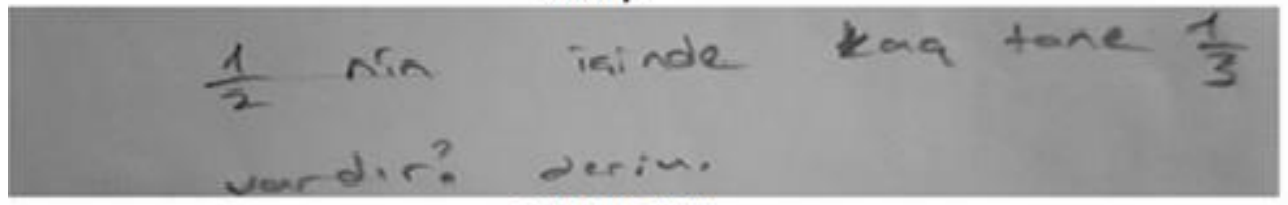

AY/SS-KG/YSZ

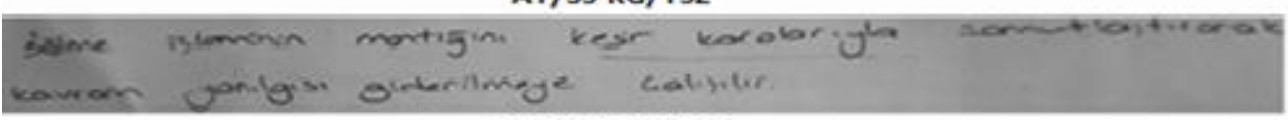

SN/MK-GSZ/YSZ

Şekil 8. BKE kategorisindeki farklı tür yanıtlar için örnek durumlar

Şekil 8'de yer alan ilk alıntıda öğretmen adayının mevcut durum için bir model oluşturduğu ve kullandığı görülmektedir. Mevcut modelin öğrencinin kavram yanılgısını giderme noktasında yeterli olduğu görülmüş ve ilgili yanıt $M K$ teması altında $G / Y$ olarak kodlanmıştır. íkinci alıntıda öğretmen adayı mevcut durum için sözel bir ifade kullanmış ve soruyu farklı bir biçimde ifade etmeye çalışmıştır. Öğretmen adayının yanıtında kullanılan ifade doğru olmakla birlikte, öğrencinin yanılgısını giderme noktasında yetersizdir. Bu nedenle ilgili yanıt AY/SS teması altında KG/YSZ olarak kodlanmıştır. Üçüncü alıntıda ise öğretmen adayı materyal kullanımını önermekle birlikte bunun nasıl yapılacağı hakkında herhangi bir açıklama yapmamıştır. Bu nedenle ilgili yanıt SN/MK teması altında GSZ/YSZ olarak kodlanmıştır.

Kesrin yarısını elde etme kategorisinde 20 öğretmen adayı $(\% 38,46)$ model kullanma yöntemini, 15 öğretmen adayı (\%28,84) açıklama yapma/soru sorma yöntemini, 3 öğretmen adayı $(\% 5,76)$ ise somut nesne/materyal kullanma yöntemini tercih etmişlerdir. Mevcut sayısal veriler incelendiğinde model kullanma ve açıklama yapma/soru sorma yöntemini tercih eden öğretmen adaylarının oranının birbirine yakın değerler olduğu, somut nesne/materyal kullanma yöntemini tercih eden öğretmen adaylarının oranının ise ortalamanın çok altında bir değer olduğu görülmektedir. Bu kategoride farklı yöntemler içerisinde yer alan G/Y, KG/YSZ ve GSZ/YSZ yanıtlar için örnek durumlar Şekil 9'da verilmektedir. 

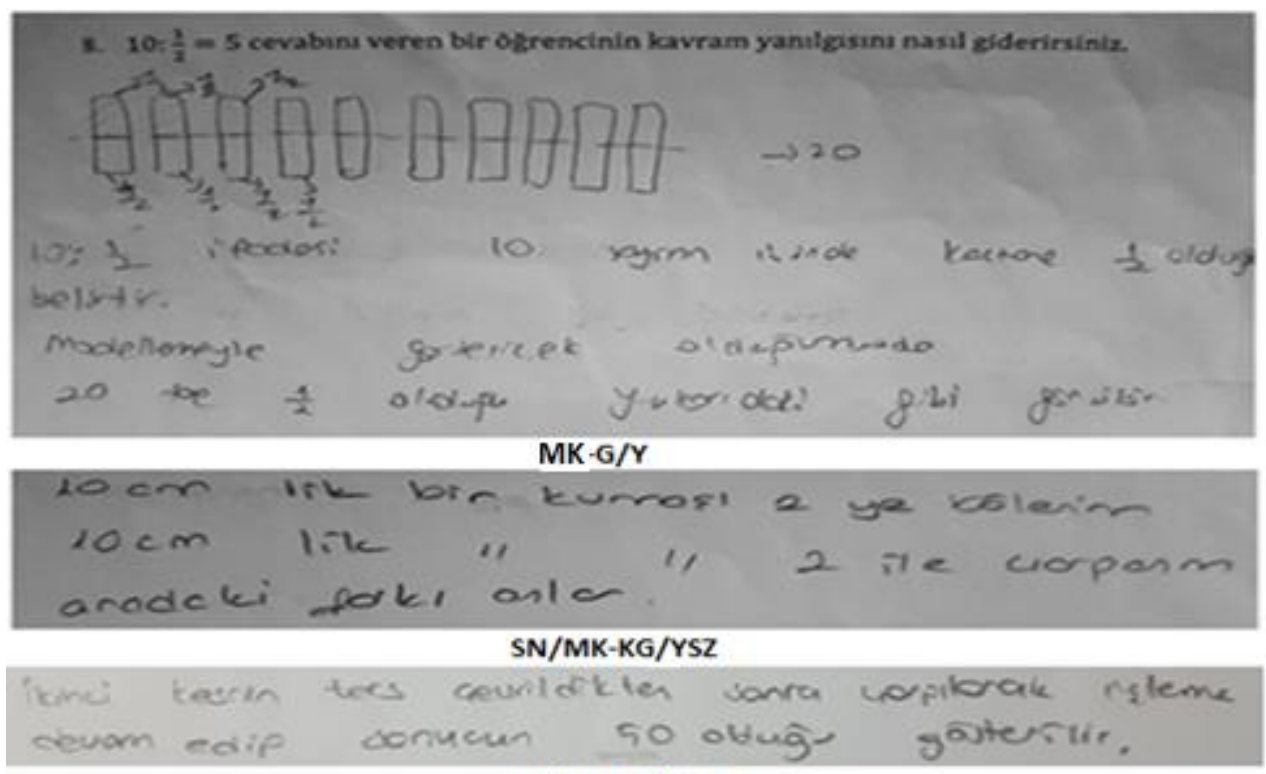

AY/SS-GSZ/YSZ

Şekil 9. KYE kategorisindeki farklı tür yanıtlar için örnek durumlar

Şekil 9'da yer alan ilk alıntıda öğretmen adayının bölme işlemi için uygun bir model kullandığı görülmektedir. Dolayısıyla ilgili yanıt MK teması altında G/Y olarak kodlanmıştır. íkinci alıntıda öğretmen adayının, 2 ye bölme ve 2 ile çarpmanın nicelikler üzerindeki etkilerini ortaya koymak amacıyla somut nesne kullandığı görülmektedir lakin oluşturulan senaryo mevcut durum ile ilişkisizdir. Zira mevcut soruda $122^{\prime}$ ye bölme durumu söz konusudur. Öğretmen adayının ilgili yanılgının giderilmesine yönelik uygun bir yöntemi tam oalrak kullanamadığı görülmektedir. Bu nedenle ilgili yanıt SN/MK teması altında KG/YSZ olarak kodlanmıştır. Üçüncü alıntıda ise öğretmen adayı bölme işlemi için yapılması gereken işlem algoritmasını vermekte ve mevcut durumun kavramsal olarak anlaşılmasına yönelik olarak herhangi bir açıklamada bulunmamaktadır. Dolayısıyla söz konusu yanıtın ilgili kavram yanılgısını giderme noktasında yetersiz olduğu kabul edilmiş ve ilgili yanıt AY/SS teması altında GSZ/YSZ olarak kodlanmıştır.

\section{2. Öğretmen Adaylarının Kesirlerde Görülen Kavram Yanılgılarını Giderme Yeterliklerine iliş̧in Bulgular}

$\mathrm{Bu}$ araştırmada yer alan öğretmen adaylarının KYGF için kullandıkları yanıt türlerinin toplamda ve ayrı ayrı her bir tema altındaki dağılımına ilişkin sayısal veriler Şekil 10'da gösterilmektedir.

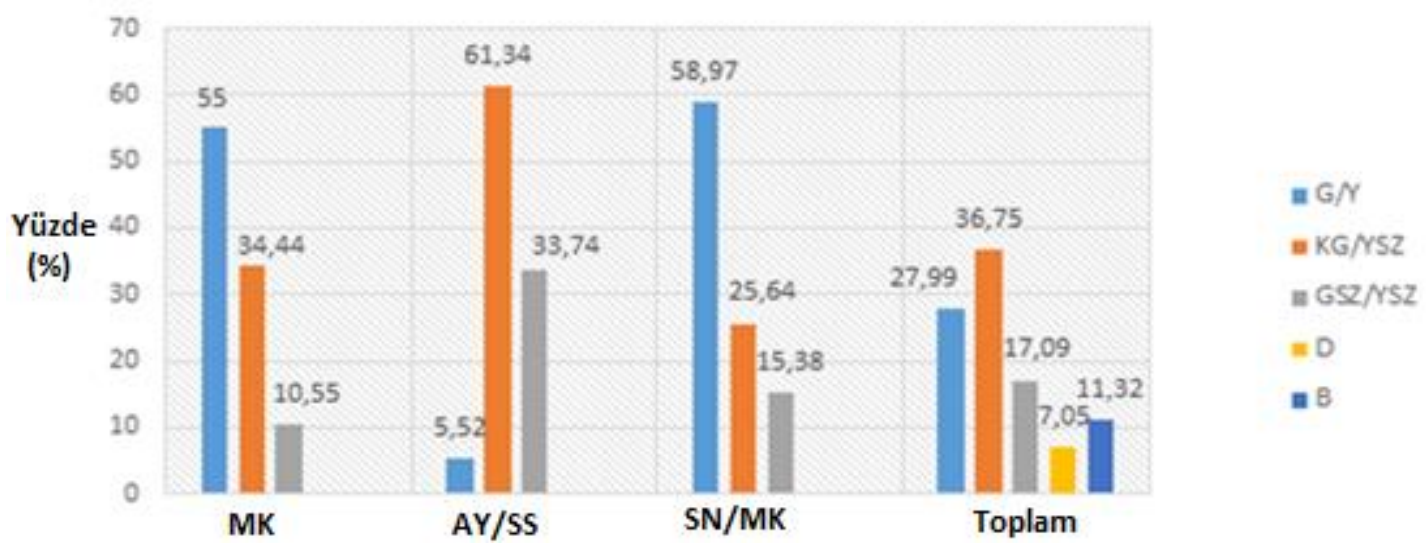

Şekil 10. Öğretmen adaylarının yanıtlarına ilişkin sayısal veriler 
Şekil 10'daki verilere göre çalışmada yer alan öğretmen adaylarının toplamda \%37'sine yakın bir bölümünün KYGF'de yer alan sorulara kısmen geçerli/yetersiz yanıtlar verdikleri görülmektedir. Bundan sonra öğretmen adaylarının \%28'ine yakın bir bölümü ise söz konusu sorulara geçerli/yeterli yanıtlar vermişlerdir. KYGF'ye verilen yanıtların nitelendirilmesi amacıyla oluşturulan yanıt türleri içerisinde boş ve diğer türündeki yanıtlar yetersiz olarak kabul edilebileceğinden öğretmen adaylarının \%35,46'sının mevcut sorulara geçersiz/yetersiz yanıtlar verdikleri söylenebilir.

KYGF'ye verilen yanıtlardan model kullanma temasında yer alanlar incelendiğinde, bu yanıtların \%55'inin geçerli/yeterli, \%35'e yakın bir bölümünün kısmen geçerli/yetersiz, \%11'e yakın bir bölümünün ise geçersiz/yetersiz oldukları görülmektedir. Dolayısıyla model kullanma teması altındaki yanıtların büyük bölümünün geçerli/yeterli olduğu söylenebilir. Açıklama yapma/soru sorma teması altındaki yanıtların oranları dikkate alındığında ise öğretmen adaylarının \%61'e yakın bir bölümünün kısmen geçerli/yetersiz, \%33'üne yakın bir bölümünün geçersiz/yetersiz, \%6'sına yakın bir bölümünün ise geçerli/yeterli yanıtlar verdikleri görülmektedir. Bu tema altındaki yanıtların büyük çoğunluğunu da kısmen geçerli/yetersiz yanıtların oluşturduğu görülmektedir. Somut nesne/materyal kullanma teması altında yer alan yanıtların \%59'a yakın bir bölümünün geçerli/yeterli olduğu görülmektedir. Bundan sonra gelen yanıtlar ise sırasıyla \%26'ya yakın bir oran ile kısmen geçerli/yetersiz ve \%15'e yakın bir oranla da geçersiz/yetersiz yanıtlardır.

3.3. MEKY Dersini Alma-Almama Değişkenine Göre Öğretmen Adaylarının KYGF Puanlarına İlişkin Bulgular

Çalışmada yer alan öğretmen adaylarının KYGF'ye vermiş oldukları yanıtların, MEKY seçmeli dersini alıp almama değişkenine göre incelenmesi sonucu elde edilen bulgular Tablo 5 'te verilmektedir.

Tablo 5

MEKY Dersini Alma/Almama Değişkenine Göre T-Testi Sonuçları

\begin{tabular}{lcccccc}
\hline & $\mathrm{N}$ & $\overline{\mathrm{X}}$ & $\mathrm{ss}$ & $\mathrm{sd}$ & $\mathrm{t}$ & $\mathrm{p}$ \\
\hline MEKY Dersini alanlar & 24 & 8,83 & 3,67 & 50 & \multirow{2}{*}{78} &, 43 \\
MEKY Dersini almayanlar & 28 & 8,03 & 3,65 & & & \\
\hline
\end{tabular}

Tablo 5'te yer alan verilere göre MEKY seçmeli dersini alan öğretmen adaylarının KYGF puan ortalamalarının $(8,83)$, söz konusu dersi almayan öğretmen adaylarının puan ortalamalarından $(8,03)$ daha yüksek olduğu fakat puanlar arasındaki farklıığın anlamlı olmadığı ( $>$ >05) görülmektedir.

\subsection{Mezun Olunan Okul Türü Değişkenine Göre Öğretmen Adaylarının KYGFPuanlarına iliş̧kin Bulgular}

Çalışmada yer alan öğretmen adaylarının KYGF'ye vermiş oldukları yanıtların, mezun olunan okul türü değişkenine göre incelenmesi sonucu elde edilen bulgular Tablo 6 ve Tablo 7'de verilmektedir.

Tablo 6

Mezun Olunan Okul Türü Değişkenine Göre Anova Testi Betimsel Sonuçları

\begin{tabular}{llll}
\hline Okul Türü & $\mathrm{N}$ & $\overline{\mathrm{X}}$ & $\mathrm{ss}$ \\
\hline Düz Lise & 15 & 7,53 & 3,39 \\
Anadolu Öğretmen Lisesi & 15 & 8,33 & 2,82 \\
Anadolu Lisesi & 20 & 8,90 & 4,41 \\
İmam-Hatip Lisesi & 2 & 10,50 & 3,53 \\
\hline
\end{tabular}


Tablo 7

Mezun Olunan Okul Türü Değişkenine Göre Anova Testi Sonuçları

\begin{tabular}{llllll}
\hline & Kareler Toplamı & sd & Kareler Ortalaması & F & p \\
\hline Gruplar arası & 25,153 & 3 & 8,384 &, 614 &, 609 \\
Gruplar içi & 655,367 & 48 & 13,653 & & \\
Toplam & 680,519 & 51 & & & \\
\hline
\end{tabular}

Tablo 6 incelendiğinde KYGF puanlarının sırasıyla imam hatip liselerinden $(10,50)$, anadolu liselerinden $(8,90)$, anadolu öğretmen liselerinden $(8,33)$ ve düz liselerden $(7,53)$ mezun olan öğretmen adaylarında daha yüksek olduğu görülmektedir. Lakin Tablo 7'deki veriler $(F(3,48)=, 614, p>.05)$ söz konusu puan farklılıklarının anlamlı olmadığını göstermektedir.

\subsection{Genel Akademik Not Ortalaması Değişkenine Göre Öğretmen Adaylarının KYGF Puanlarına İlişkin Bulgular}

Öğretmen adaylarının genel akademik not ortalamaları ile KYGF puanları arasındaki ilişkinin belirlenmesine yönelik olarak gerçekleştirilen basit korelasyon analizi sonucunda iki değişken arasında düşük düzeyde bir ilişki $(r=, 177)$ olduğu görülmüştür.

\section{SONUÇLAR ve TARTIŞMA}

$\mathrm{Bu}$ araştırmada geleceğin öğretmenleri olan öğretmen adaylarının, matematik eğitiminde kavramların öğrenciler tarafından tam olarak anlaşılamaması sonucu ortaya çıkan ve oldukça sık rastlanılan kavram yanılgılarını giderme hususunda pedagojik alan bilgilerini kullanma yeterlikleri incelenmeye çalışılmıştır. Çalışma kapsamında farklı alt problemlere yanıtlar aranmaya çalışılmış ve söz konusu problemlerle ilişkili olarak bazı sonuçlar elde edilmiştir. Araştırmanın bu bölümünde bu sonuçlar sırasıyla verilerek alan yazınla ilişkili olarak tartışılmaya çalışılmıştır.

Araştırma sonucunda kesirlerle ilgili kavram yanılgılarını gidermek amacıyla öğretmen adaylarının genellikle model kullanma ve açıklama yapma/soru sorma yöntemlerini tercih ettikleri görülmüştür. Bu iki yöntemi tercih eden öğretmen adaylarının oranları birbirine oldukça yakındır. Öğretmen adaylarının yanıtları incelendiğinde açıklama yapma/soru sorma teması altındaki yanıtların tamamen geleneksel bir anlayış içerisinde yapılandırıldığı, açıklama yapma sürecinde kullanılan soruların ise öğrencilerin kavramları veya matematiksel ilişkileri keşfetmesine büyük oranda hizmet etmediği, yapılandırmacı yaklaşıma dayalı bireyi aktif tutan ve keşfetmesine imkân veren stratejileri kullanan öğretmen adaylarının sayısının oldukça sınırlı olduğu görülmüştür. Bununla birlikte geleneksel bir anlayış içerisinde yapılan açıklamaların dahi öğrencilerin yanılgılarını giderecek niteliğe sahip olmadığı, bu tür yanıtların \%61'inin kısmen geçerli ve yetersiz olmasına bağlı olarak söylenebilir. Söz konusu kodlamanın özelliğine bağlı olarak bu yanıtları veren öğretmen adayları, öğrenciye neyin anlatılması veya öğrencinin neyi farketmesi gerektiğini doğru biçimde ifade edebilmiş lakin bunun nasıl yapılacağı hususunda yetersiz kalmışlardır. Kavram yanılgısına sahip bir öğrenciye yanılgısını giderecek seviyede açıklama yapabilen öğretmen adaylarının oranının sadece $\% 5$ olduğu görülmüştür. Öğretimsel açıklamalar pedagojik alan bilgisinin en önemli boyutlarından biri olmasına rağmen, alan yazında yapılan araştırmalar (Henningsen ve Stein, 1997; Gökkurt-Özdemir \& Soylu, 2017; Kinach, 2002a, 2002b; Kılcan, 2006; Şahin, Gökkurt, \& Soylu, 2016) öğretmenlerin ve öğretmen adaylarının kullandıkları öğretimsel açıklamaların genellikle anlamadan çok ezbere dayalı ve dolayısıyla kural ve işlem odaklı olduğunu göstermektedir. Borko ve Putnam (1996), Prawat (1992), Richardson (1996) ve Thompson (1992) ise bu durumun nedenlerinden bazıları olarak öğretmenlerin 
matematik bilgilerinin yetersizliği ve matematiğe ilişkin inançlarını göstermektedirler (aktaran Uçar, 2011). Bununla ilişkili olarak söz konusu çalışmalarda yeterli düzeyde kavramsal bilgisi olmayan bir öğretmenin kullanacağı açıklamaların da kavramsal düzeyde olmayacağı ve matematiği bir kurallar bütünü olarak gören bir öğretmenin açıklamalarının da kural temelli olacağı ifade edilmektedir.

Model kullanma yöntemini kullanarak öğrenci yanılgılarını gidermede yeterli görülen öğretmen adaylarının oranı \%55'tir. Dolayısıyla öğretmen adaylarının model kullanma yöntemini kullanma hususunda, açıklama yapma/soru sorma yöntemini kullanmadan daha başarılı oldukları söylenebilir. Bununla birlikte bu kategoride yer alan yanıtların küçümsenmeyecek bir miktarının $(\% 44,99)$ ise yetersiz yanıtlardan oluştuğu görülmektedir. Öğretmen adaylarının yanıtları incelendiğinde model kullanma yöntemini kullanmada yetersiz olunan ilk üç soru kategorisi, bölmenin kesirlere etkisi, kısımlara ayırma ve kesrin yarısını elde etme kategorileridir. Dolayısıyla öğretmen adaylarının özellikle kesirlerle bölme işlemi için uygun model oluşturmada güçlük çektikleri söylenebilir. Alan yazında yapılan farklı çalışmalarda da (Ball, 1990a; Leinhardt ve Smith, 1985; Ma, 1999; McDiarmid ve Wilson, 1991; Post vd., 1991; Tirosh, 2000) öğretmen adaylarının özellikle kesirlerle bölme işlemi için model oluşturma ve işlem algoritmasını anlamlandırmada güçlük çektikleri ifade edilmektedir. Kısımlara ayırma kategorisinde yer alan soru için öğretmen adaylarının özellikle model kullanma yöntemini tercih etmelerine rağmen söz konusu modelleri yeterli düzeyde kullanamamaları ise öğretmen adaylarının alan bilgilerinin sınırlılı̆ı ile ilişkilendirilebilir. Zira bir kesrin parça-bütün anlamını ortaya koyan matematiksel modelde neden parçaların birbiri ile eşit büyüklükte olması gerektiği sorusuna tatmin edici bir yanıt verebilen öğretmen adaylarının sayısı oldukça azdır. Bu soruda öğretmen adaylarının yanıtlarının büyük bir bölümü açıklama yapma/soru sorma yöntemini içermektedir ve bu yöntemi tercih eden öğretmen adaylarının büyük bir çoğunluğu bu soruda kesirlerin gösteriminde parçaların eşit olması gerekir biçiminde açıklama yapmışlardır. Bunun gerekçesini ortaya koyabilen öğretmen adayları ise yok denecek kadar azdır.

Model kullanma teması altında yer alan yanıtlarla ilgili olarak bu araştırmada elde edilen bir diğer sonuç ise, öğretmen adaylarının genel olarak kendilerine öğretilen belirli kavramsal modelleri kullandıkları ve bunun dışına çok fazla çıkmamaları olmuştur. Öğretmen adayları tarafından oluşturulmuş duruma özgü kavramsal modellere çok az rastlanmıştır. Bu duruma örnek olarak RAB, ÇKE, BKE, KYE kategorilerindeki sorular gösterilebilir. Özel olarak RAB kategorisindeki soru için model kullanma yöntemini tercih eden öğretmen adaylarının tamamı bir bütünü iki eş parçaya ayırma ve parçalardan birini tarama yoluna gitmişlerdir. Bunun dışında farklı bir matematiksel model kullanan öğretmen adayına rastlanmamıştır. Bununla birlikte ÇKE, BKE ve KYE kategorilerindeki öğretmen adaylarının tamamının derslerde kendilerine gösterilmiş olan alan modellerini kullandıkları, farklı matematiksel modellere genel olarak yer vermedikleri gözlenmiştir. McDiarmid vd. (1989), öğretmenlerin kavramlar için farklı gösterimler oluşturabilmelerini için kavramları derinlemesine anlamaları gerektiğini ifade etmektedirler. Dolayısıyla burada elde edilen sonuçlar öğretmen adaylarının alan bilgileri ve buna bağlı oalrak pedagojik alan bilgilerinin kısmen de olsa yetersizliği ile ilişkilendirilebilir. Zira Ma $(1996,1999)$ yeterli düzeyde alan bilgisi olmayan bir öğretmenin ilgili konuda pedagojik alan bilgisinin de yeterli düzeyde gelişemeyeceğini söylemektedir.

Kavram yanılgılarının türleri dikkate alındığında öğretmen adaylarının kesirlerin karşılaştırılması, hatalı kesir toplamı, çarpmanın kesirlere etkisi ve kesrin yarısını elde etme 
kategorilerinde yer alan sorularda model kullanma yöntemini ağıllıklı olarak tercih ettikleri ve genel olarak yeterli biçimde kullanabildikleri gözlenmiştir. Bunun yanında kısımlara ayırma, bileşik kesirlerde birimin belirlenememesi ve bölmenin kesirler etkisi kategorilerinde yer alan sorularda öğretmen adaylarının genel olarak açıklama yapma/soru sorma yöntemini tercih ettikleri görülmüştür. Kesirlerde kısımlara ayırma ve bileşik kesirlerde birimin belirlenememesi kategorilerinde yer alan sorularda öğrenciler tarafından yanlı̧̧ olarak oluşturulmuş belirli matematiksel modellerin varlığı söz konusudur. Dolayısıyla bu sorularda öğretmen adaylarından beklenen, söz konusu modellerin kesirlerle doğru biçimde ilişkilendirilmesi ve öğrenciye sahip olduğu yanılgının nedenlerinin, soruda yer alan matematiksel modelden yararlanılarak gösterilmesidir. Öğretmen adaylarının model kullanma yerine söz konusu yanılgıları düzeltmek için açıklama yapma yöntemini tercih etmeleri, söz konusu durumlara ilişkin matematiksel modelleri oluşturma ve kendilerine özgü biçimde kullanma noktasında çok yeterli olmadıkları izlenimi uyandırmaktadır. Öğrencilerin kesirlerle ilgili yaşadıkları güçlükleri ve yanılgıları giderme noktasında matematiksel model kullanma etkili bir yöntem olmakla birlikte (Ball, 1993; Behr, Lesh, Post ve Silver, 1983; de Castro, 2008; Erdem, 2015; Lamon, 1996; Parmar, 2003), yapılan farklı çalışmalarda (Çelik ve Çiltaş, 2015; Tuna vd., 2013; Akgün vd., 2013; Bayazıt vd., 2011) matematik öğretmenlerinin ve öğretmen adaylarının kesirler konusundaki matematiksel durumları uygun modeller geliştirerek kullanma noktasında eksikliklerinin olduğu belirtilmektedir. Kesirlerde miktarın referans alınan bütüne bağlı olması kategorisinde öğretmen adaylarının çoğunun somut nesne/materyal kullanma yöntemini tercih ettikleri ve genel olarak doğru biçimde kullanabildikleri görülmüştür. Burada elde edilen sonuç yanılgı kategorisinin niteliği ile ilişkilendirildiğinde olası bir sonuç olarak yorumlanabilir.

Öğretmen adaylarının yanıtlarının niteliği göz önüne alındığında, öğretmen adaylarının \%37'sine yakın bir bölümünün kısmen geçerli fakat yetersiz yanıtlar verdikleri görülmüştür. Daha açıkça ifade edilirse öğretmen adayları, öğrencilerin kavram yanılgılarını gidermeye yönelik doğru yöntemi ifade edebilmiş fakat bu yöntemin nasıl kullanılacağı hususunda yetersiz kalmışlardır. Dolayısıyla elde edilen bu sonuç öğretmen adaylarının pedagojik alan bilgilerinin, öğretim stratejileri bilgisi bağlamında yetersizliği hakkında ipuçları vermektedir. Öğretmen adaylarının toplamda \%35,46 sı geçersiz ve yetersiz yanıtlar verirken, \%28'e yakın bir bölümünün ise geçerli ve yeterli yanıtlar verdikleri görülmüştür. Elde edilen bu sonuç alan yazında yer alan farklı çalışma sonuçları ile benzerlik taşımaktadır. Gökkurt vd. (2013) sınıf öğretmeni adaylarının kesirlerle ilgili pedagojik alan bilgilerini öğrenci hataları açısından ele alarak inceledikleri çalışmalarında öğretmen adaylarının çoğunun kesirlerde sıralama, toplama, çıkarma ve çarpma işlemlerinde yapılan öğrenci hatalarının giderilmesiyle ilgili pedagojik alan bilgilerinin yeterli düzeyde olmadığı sonucunu elde etmişlerdir. Literatür incelendiğinde de birçok çalışma, benzer şekilde öğretmen adaylarının kesirler konusuna yönelik pedagojik alan bilgilerinin yeterli düzeyde olmadığını ortaya çıkarmıştır (Ball, 1990a, 1990b; Işıksal, 2006; Gökkurt vd., 2012; Lubinski vd., 1998; Ma, 1999; Nagle ve McCoy, 1999; Tirosh, 2000; Toluk-Uçar, 2009; Toluk-Uçar, 2011; aktaran Gökkurt vd., 2013).

Araştırma sonuçları farklı soru kategorileri için gözden geçirildiğinde öğretmen adaylarının yetersiz yanıtlar verdikleri soru kategorilerinin genel olarak kesirlerle işlemleri ve kesir kavramının anlamını içeren kategoriler olduğu görülmüştür. Bu kategorilerde yer alan yanıtlar, öğrenci yanılgılarının giderilmesine yönelik geçerli bir matematiksel açıklama veya gösterim oluşturma noktasında genel olarak yetersiz kalmışlardır. Öğrenci yanılgılarının giderilmesine yönelik olarak yapılan açıklamaların ise genel olarak kural temelli oldukları 
görülmüştür. Dolayısıyla elde edilen bu sonuç, öğretmen adaylarının alan bilgilerinin yetersizliği hakkında ipuçları vermektedir zira McDiarmid vd. (1989), Borko vd. (1992) ile Ma (1999) öğretmenin kavramsal açıdan doğru temsiller oluşturabilmesi için öncelikle kendisinin bu kavram ya da işlemleri kavramsal düzeyde anlaması gerektiğini ifade etmektedirler. Benzer şekilde Stoddart vd. (1993), öğrencilerin anlamasına yönelik etkili stratejiler geliştirmek isteyen bir öğretmenin öncelikle ilgili kavramla ilgili kendisinin alan bilgisini sorgulaması gerektiğini söylemektedir. Öğretmen adaylarının kesirlerle ilgili alan bilgilerinin yetersizliğinin nedenleri, muhtemelen okul sıralarında kesir kavramını geleneksel yollarla öğrenmiş olmaları, ezberi bir takım kurallarla kesir işlemlerini yürütmeleri ve nedenlerini sorgulamamalarına bağlı olarak yorumlanabilir. Dolayısıyla öğretmen adaylarının bilgi edinme yollarının, bilgiyi öğretme yöntemlerini de etkilediği söylenebilir.

Araştırmada, öğretmen adaylarının yanıtlarının niteliğinin, mezun oldukları okul türü, akademik başarı ve MEKY seçmeli dersini alıp almama değişkenlerine göre anlamlı farklılıklar göstermediği sonucu elde edilmiştir. Elde edilen bu sonuç, öğretmen adaylarının pedagojik alan bilgilerinin niteliğinde, söz konusu değişkenlerin önemli bir etkisi olmadığı şeklinde yorumlanabilir. Öğretmen adaylarının okul türlerinin $P A B$ ile ilişkisinin zayıf olması, geçmiş akademik yaşantılarındaki başarılarının PAB'ın gelişimini etkilemediği biçiminde yorumlanabilir. Zira, PAB, büyük oranda lisans öğrenimi sırasında ve meslek yaşamı boyunca geliştirilebilecek bir yeterliktir. Akademik başarı değişkeninin, PAB ile ilişkisinin zayıf olması, lisans öğrenimi boyunca alınmış olan derslerin kapsam ve içeriği ile ilişkili olarak yorumlanabilir. Çünkü, lisans öğrenimi boyunca öğretmen adayları alan eğitimi ve meslek dersleri almakla birlikte, alan dersleri de almaktadırlar. Özel bir matematik kavramıyla ilişkili kavram yanılgılarının giderilmesine yönelik olarak öğretmenin sahip olması gereken yeterlikler, ağılıklı olarak alan eğitimi ve meslek dersleri ile kazanılabilecek niteliktedir, hâlbuki öğretmen adaylarının akademik başarılarında tüm dersler etkili olmaktadır. Dolayısıyla burada elde edilen sonuç, bu şekilde yorumlanabilir. MEKY dersinde ise öğretmen adaylarına öğretim süreçlerinde karşılaşılabilecek kavram yanılgıları ve bunların türleri hakkında bilgi verilmekte, söz konusu yanılgıların nedenleri ve giderilmesine yönelik tartışmalar yürütülmektedir. Bununla birlikte öğrenci yanılgılarını gidermeye yönelik etkinliklere çok fazla yer verilmemekte, bu etkinlikleri geliştirmeleri öğretmen adaylarından beklenmektedir. Bu araştırma kapsamında MEKY dersini alıp almama değişkenine göre elde edilen sonuçlar ise bu şekilde yorumlanabilir. PAB, bireysel olarak farklılık göstermekle birlikte temelleri lisans öğrenimi boyunca alınacak ve öğretmenlik deneyimi ile birlikte gelişme gösterecek bir yeterliktir (Van Driel vd., 2001). Bu nedenle bu araştırmanın nicel boyutundan elde edilen sonuçlarda PAB'ın söz konusu özelliğinin etkili olduğu düşünülmektedir.

\section{5. ÖNERILER}

Bu araştırmada öğretmen adaylarının PAB'ları, özel bir matematik kavramıyla ilişkili olarak sahip olunabilecek yanılgıları giderme bağlamında ele alınarak incelenmiştir. Araştırma

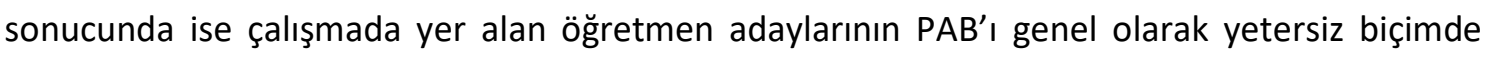
kullandıkları görülmüştür. PAB'ın kazanıldığı ilk basamak olan lisans öğrenimi süreci ve özelliği, hiç kuşkusuz elde edilen bu sonuçla ilişkilidir. Ülkemizde öğretmen yetiştiren kurumların matematik öğretmenliği lisans ders programlarında, PAB'ın gelişimine yönelik farklı dersler olmakla birlikte, bu derslerin büyük çoğunluğu teorik boyutta verilmektedir. Özel Öğretim Yöntemleri I-II dersleri dışında, matematiksel kavramların farklı özelliklerine bağlı olarak farklı stratejilerin kullanımı süreçlerini ele alan ve bu süreçlerde öğretmen adaylarının 
performanslarını ortaya çıkaran dersler maalesef oldukça sınırlıdır. Bu bağlamda söz konusu programların içeriğinin geliştirilmesi önerilmektedir. İlgili programlara, alan eğitimi dersleri kapsamında matematiksel kavramlar ve bu kavramların öğretimini konu alan yeni dersler eklenebilir. Bu derslerde özel olarak, belirli konuların öğretimine odaklanılabilir ve bu konularda ortaya çıkabilecek olası öğrenci yanılgıları ve hataları ortaya konularak, bunların giderilmesine yönelik öğretim yöntem ve stratejilerinin neler olabileceği tartışılabilir. Ayrıca öğretmen adaylarının öğretmenlik mesleği ile ilgili olarak ilk deneyimi kazandıkları Okul Deneyimi ve Öğretmenlik Uygulaması gibi derslerin öğretim programlarında daha fazla yer almasıyla, PAB'ı geliştirmeleri noktasında kendilerine fırsatlar sunulabilir. Zira Gökkurt vd. (2016) ile Kovarik (2008), ülkemizdeki hizmet oncesi oğretmen eğitimi sürecinin pedagojik alan bilgisinin gelişimi açısından yetersiz olduğunu belirtmektedir.

Pedagojik alan bilgisi, öğretmenlerin etkili öğretim yapabilmelerini sağlayan en etkili faktör olmakla birlikte, alan yazında konu ile ilgili çok kısıtlı araştırma olduğu görülmektedir. Özellikle kavram yanılgıları söz konusu olduğunda ise mevcut çalışmaların çoğunlukla öğrencilerle yürütüldüğü ve kavram yanılgılarını belirlemeye yönelik olduğu görülmektedir. Kavram yanılgılarının farkına varmak önemli olmakla birlikte, giderilmesi noktasında pedagojik alan bilgisinin kullanımı da hiç kuşkusuz önem arz etmektedir. Bu nedenle konu ile ilgili alan yazında farklı kavramların öğretim durumlarını ele alan çalışmaların yapılması önerilmektedir zira bu araştırma belirli bir matematik konusu ile sınırlıdır. Farklı olarak yürütülecek araştırmalarda ayrıca, PAB'ın farklı boyutları özel olarak ele alınarak tartışılabilir. PAB üzerine yapılacak spesifik çalışmaların hiç kuşkusuz alan yazına katkısı büyük olacaktır.

\section{KAYNAKLAR}

Akgün, L., Çiltaş, A., Deniz, D., Çiftçi, Z., \& Işık A. (2013). Illköğretim matematik öğretmenlerinin matematiksel modelleme ile ilgili farkındalıkları. Adıyaman Üniversitesi Sosyal Bilimler Enstitüsü Dergisi, 12(6), 1-34.

Aksu, M. (1997). Student performance in dealing with fractions. The Journal of Educational Research, 90 (6), 375-380.

Alacacı, C., (2010). Öğrencilerin kesirler konusundaki kavram yanılgıları. E. Bingölbali ve M.F. Özmantar (Ed.), Matematiksel zorluklar ve çözüm önerileri içinde (s. 63-95). Ankara: PegemA Yayıncilık.

Ball, D. L. (1990a). Prospective elementary and secondary teachers' understanding of division. Journal for Research in Mathematics Education, 21, 132-144.

Ball, D. L. (1990b). The mathematical understandings that prospective teachers bring to teacher education. The Elementary School Journal, 90, 449-469.

Ball, D. L. (1993). Halves, pieces, and twoths: Constructing and using representational contexts in teaching fractions. T. P. Carpenter, E. Fennema, \& T. A. Romberg (Ed.), In Rational numbers: An integration of research (pp. 157-195). Hillsdale, NJ: Lawrence Erlbaum Associates, Inc. 
Bayazit, i., Aksoy, Y., \& Kırnap, M. (2011). Öğretmenlerin matematiksel modelleri anlama ve model oluşturma yeterlilikleri. Nwsa: Education Sciences, 6 (4), 2495-2516.

Behr, M. J., Lesh, R., Post, T., \& Silver, E. A. (1983). Rational number concepts. R. Lesh, \& M. Landau (Ed.), In Acquisition of mathematics concepts and processes (pp. 91-126). New York: Academic Press.

Behr, M., Harel, G., Post, T. R., \& Lesh, R. (1993). Rational Number: Towards a semantic analysis. T. Carpenter, E. Fennema, \& T. Romberg (Ed.), In Rational numbers: An integration of research (pp. 13-47). Hillsdale, NJ: Erlbaum.

Bezuk, N. S., \& Bieck, M. (1993). Current research on rational numbers and common fractions: summary and implications for teachers. D. T. Owens (Ed.), In Research ideas for the classroom middle grades mathematics (pp. 118 - 136). New York: MacMillan.

Bigalke, H.G., \& Hasemann, K. (1978). Zur Didaktik der Mathematik in den Klassen 5 and 6, Band 2. Frankfurt: Diester weg.

Booker, G. (1998). Children's construction of Initial fraction concepts. In proceedings of the 22. Conference of the International Group for the Psychology of Mathematics Education. Stellenbosh, South Africa. 2, 128-135.

Borko, H., \& Putnam, R. (1996). Learning to teach. D. Berliner, \& R. Calfee (Ed.), In Handbook of educational psychology (pp. 673-708). New York: Macmillan.

Borko, H., Eisenhart, M., Brown, C. A., Underhill, R. G., Jones, D., \& Agard, P. C. (1992). Learning to teach hard mathematics: Do novice teachers and their instructors give up too easily? Journal for Research in Mathematics Education, 23, 194-222.

Charalambous, C. Y., \& Pitta-Pintazi, D. (2005). Revisiting a theoretical model on fractions: implications for teaching and research. Chick, H. L. \& Vincent, J. L. (Eds.). In Proceedings of the 29th conference of the international group for the psychology of mathematics education, 2, 233-240.

Creswell, J., \& Plano Clark, V. L. (2007). Understanding mixed methods research. J. Creswell (Ed.), In Designing and conducting mixed methods research (pp. 1-19). Thousand Oaks, CA: Sage.

Çelik, B., \& Çiltaş, A. (2016). Beşinci sınıf kesirler konusunun öğretim sürecinin matematiksel modeller açısından incelenmesi. Bayburt Eğitim Fakültesi Dergisi, 10 (1), 180-204.

Davis, E. G. (2003). Teaching and classroom experiments dealing with fractions and proportional reasoning. Journal of Mathematical Behavior, 22, 107-111.

de Castro, B. (2008). Cognitive models: the missing link to learning fraction multiplication and division. Asia Pacific Education Review, 9(2), 101-112.

Dickson, L., Brown, M., \& Gibson, O. (1993). Children learning mathematics: a teacher's guide to recent research. London: Cassell.

Erbilgin, E., Şahin, B., \& Arıkan, S. (2017). Pasta dilimlerinin fiyatı ne kadar? Journal of Inquiry Based Activities, 5(1), 34-47. 
Erdem, E. (2015). Zenginleştirilmiş öğrenme ortamının matematiksel muhakeme ve tutuma etkisi. (Yayınlanmamıs doktora tezi). Atatürk Üniversitesi, Erzurum.

Gökkurt, B., Şahin, Ö., \& Soylu, Y. (2012). Matematik öğretmenlerinin matematiksel alan bilgileri ile pedagojik alan bilgileri arasındaki ilişkinin incelenmesi. The Journal of Academic Social Science Studies, 5(8), 997-1012.

Gökkurt, B., Şahin, Ö., \& Soylu, Y. (2016). Öğretmen adaylarının değişken kavramına yönelik pedagojik alan bilgilerinin öğrenci hataları bağlamında incelenmesi. Pamukkale Üniversitesi Eğitim Fakültesi Dergisi, 39, 17-31.

Gökkurt, B., Şahin, Ö., Soylu, Y., \& Soylu, C. (2013). Examining pre-service teachers' pedagogical content knowledge on fractions in terms of students' errors. International Online Journal of Educational Sciences, 5(3), 719-735.

Hanson, D. (1995). Understanding Fractions (Grades 5 to 8). http://mathcentral.uregina.ca/RR/database/RR.09.95/hanson4.html (Erişim Tarihi: 2017, 10 Haziran).

Hart, K. M. (1987). Practical work and formalisation, too great a gap. J. C. Bergeron, N. Herscovicsi, \& C. Kieran (Ed.). In Proceedings of the eleventh international conference psychology of mathematics education. (pp. 408-415). Montreal: The University of Montreal.

Hart, K. M. (1981). Fractions. K. M. Hart (Ed.), In Children's understanding of mathematics: 1116 (pp. 66-81). London: John Murray.

Hasemann, K. (1981). On difficulties with fractions. Educational Studies in Mathematics, 12(1), 71-87.

Henningsen, M., \& Stein, M. K. (1997). Mathematical tasks and student cognition: Classroombased factors that support and inhibit high-level mathematical thinking and reasoning. Journal for Research in Mathematics Education, 28, 524-549.

Işık, C., \& Kar, T. (2012). 7. sınıf öğrencilerinin kesirlerde toplama işlemine kurdukları problemlerin analizi. Ilköğretim Online, 11(4), 1021-1035.

Işıksal M., \& Osmanoğlu, A. (2016). Pedagojik alan bilgisi. Erhan Bingölbali, Selahattin Arslan, İsmail Özgür Zembat (Ed.), Matematik eğitiminde teoriler içinde (s. 677-699). Ankara: Pegem.

Işıksal, M. (2006). Ilköğretim matematik öğretmen adaylarının kesirlerde çarpma ve bölmeye ilişkin alan ve pedagojik içerik bilgileri üzerine bir çalışma. (Yayımlanmamış doktora tezi). Orta Doğu Teknik Üniversitesi, Ankara.

Kabapınar, F. (2003). Kavram yanılgılarının ölçülmesinde kullanılabilecek bir ölçeğin bilgikavrama düzeyini ölçmeyi amaçlayan ölçekten farklılıkları. Kuram ve Uygulamada Eğitim Yönetimi, 35(35), 398-417.

Karaağaç, M. K., \& Köse, L. (2015). Öğretmen ve öğretmen adaylarının öğrencilerin kesirler konusundaki kavram yanılgıları ile ilgili bilgilerinin incelenmesi. Sakarya Üniversitesi Eğitim Fakültesi Dergisi, 30, 72-92. 
Kılcan, S. (2006). Ilköğretim matematik öğretmenlerinin kavramsal bilgileri: Kesirlerle bölme. (Yayınlanmamış Yüksek Lisans Tezi). Abant İzzet Baysal Üniversitesi, Bolu.

Kinach, B. M. (2002a). Understanding and learning-to-explain by representing mathematics: Epistemological dilemmas facing teacher educators in the Secondary mathematics "methods" course. Journal of Mathematics Teacher Education, 5, 153-186.

Kinach, B.M. (2002b). A cognitive strategy for developing prospective teachers" pedagogical content knowledge in the secondary mathematics methods course: Toward a model of effective practice. Teaching and Teacher Education, 18(1), 51-71.

Kovarik, K. (2008). Mathematics educators' and teachers' perceptions of pedagogical content knowledge. (Unpublished doctoral dissertation). Columbia University, New York.

Lamon, S. J. (1996). The development of unizing: its role in children's partitioning strategies. Journal for Research in Mathematics Education, 27(2), 170-193.

Leinhardt, G., \& Smith, D. A. (1985). Expertise in mathematics instruction: Subject matter knowledge. Journal of Educational Psychology, 77, 247-271.

Lubinski, C. A., Fox, T., \& Thomason, R. (1998). Learning to make sense of division of fractions: one K-8 pre-service teacher's perspective. School Science and Mathematics, 98(5), 247253.

Ma, L. (1996). Profound understanding of fundamental mathematics: What is it, why is it important, and how is it attained. (Unpublished doctoral dissertation). Stanford University, CA.

Ma, L. (1999). Knowing and teaching elementary mathematics: teachers' understanding of fundamental mathematics in china and the United States. Mahwah, NJ: Lawrence Erlbaum Associates.

Mack, N. K. (1990). Learning fractions with understanding: Building on informal knowledge. Journal for Research in Mathematics Education, 21, 16-32.

Mack, N. K. (1995). Confounding whole-number and fraction concepts when building on informal knowledge. Journal for Research in Mathematics Education, 26(5), 422-441.

Mason, J. (2006). Mixing methods in a qualitatively driven way. Qualitative Research, 6 (1), 925.

McDiarmid, G. W., \& Wilson, S. M. (1991). An exploration of the subject matter knowledge of alternate route teachers: Can we assume they know their subject? Journal of Teacher Education, 42, 93-103.

McDiarmid, G. W., \& Ball, D. L. (1989). The teacher education and learning to teach study: An occasion for developing a conception of teacher knowledge. East Lansing, MI: The National Center for Research on Teacher Education.

Miles, M. B., \& Huberman, A. M. (1994). An Expanded Sourcebook Qualitative Data Analysis. United States of America: Sage Publications. 
Mok, I., Cai, J., \& Fong-Fung, A. (2008). Missing learning opportunities in classroom instruction: evidence from an analysis of a well-structured lesson on comparing fractions. The Mathematics Educator, 11(1-2), 111-126.

Moss, J., \& Case, R. (1999). Developing children's understanding of the rational numbers: A new model and an experimental curriculum. Journal for research in mathematics education, 30, 122-147.

Nagle, L. M., \& Mccoy, L. P. (1999). Division of fractions: procedural versus conceptual knowledge. In McCoy, L.P. (Ed.), In Studies in teaching: 1999 research digest (pp.81-85). Research projects presented at annual Research Forum (Winston-Salem, NC). ERIC Document Reproduction Service No: ED 443814.

Newstead, K., \& Murray, H. (1998). Young student's construction of fractions. Proceeding of the 22nd Conference of the International Group for the Psychology of Mathematics Education. Stellenbosh, South Africa, 295-302.

Okur, M., \& Gürel, Z. Ç. (2016). Ortaokul 6. ve 7. sınıf öğrencilerinin kesirler konusundaki kavram yanılgıları. Erzincan Üniversitesi Eğitim Fakültesi Dergisi, 18(2), 922-952.

Padberg, F., \& Wartha, S. (1978). Didaktik der Bruchrechnung. Freiburg: Herder.

Pantziara, M., \& Philippou, G. (2011). Levels of students' “conception” of fractions. Educational Studies in Mathematics, 79 (1), 61-83.

Parmar, R. (2003). Understanding the concept of "division": assessment considerations. Exceptionality. 11(3), 177-189. http://dx.doi.org/10.1207/S15327035EX1103_05. (Erişim Tarihi: 2017, 17 Haziran).

Patton, M. Q. (1987). How to use qualitative methods in evaluation (No. 4). California: Sage Publications, Inc.

Patton, M. Q. (2014). Nitel araştırma ve değerlendirme yöntemleri. (Çeviri Editörleri: Mesut Bütün ve Selçuk Beşir Demir). Ankara: Pegem Akademi.

Post, T. R., Harel, G., Behr, M., \& Lesh, R. (1991). Intermediate teachers' knowledge of rational number concepts. E. Fennema, T. P. Carpenter, \& S. J. Lamon (Eds.), In Integrating research on teaching and learning mathematics (pp. 177-198). Albany, NY: State University Press of New York.

Prawat, R. S. (1992). Teachers' beliefs about teaching and learning: A constructivist perspective. American Journal of Education, 100 (3), 354-395.

Reys, R. E., Suydam, M.N., \& Lindquist, M. M., \& Smith, N. L. (1998). Helping Children Learn Mathematics. Boston: Allen and Bacon.

Richardson, V. (1996). The role of attitudes and beliefs in learning to teach. J. Sikula (Ed.), In Handbook of research on teacher education (pp. 102-119). New York: Macmillan.

Shulman, L. S. (1986). Those who understand: Knowledge growth in teaching. Educational Researcher, 15 (2), 4-14. 
Soylu, Y., \& Soylu, C. (2005). İlköğretim beşinci sınıf öğrencilerinin kesirler konusundaki öğrenme güçlükleri: kesirlerde sıralama, toplama, çıkarma, çarpma ve kesirlerle ilgili problemler. Erzincan Eğitim Fakültesi Dergisi, 7(2), 101-117.

Stoddart, T., Connell, M., Stofflett, R., \& Peck, D. (1993). Reconstructing elementary teacher candidates' understanding of mathematics and science content. Teacher and Teacher Education, 9, 229-241.

Şahin, Ö., Gökkurt, B., \& Soylu, Y. (2016). Examining prospective mathematics teachers' pedagogical content knowledge on fractions in terms of students' mistakes. International Journal of Mathematical Education in Science and Technology, 47(2), 531-551.

Thompson, A. G. (1992). Teachers" beliefs and conceptions: A synthesis of the research. In D. A. Grouws (Ed.), In Handbook of research on mathematics teaching and learning (pp. 127146). New York: Macmillan.

Thompson, A. G. (1993). Quantitative reasoning, complexity and additive structures. Educational Studies in Mathematics, 25(3), 165-208.

Tirosh, D. (2000). Enhancing prospective teacher' knowledge of children's conceptions: The case of division of fractions. Journal for Research in Mathematics Education, 31(1), 5-25.

Toluk-Uçar, Z. (2009). Developing pre-service teachers understanding of fractions through problem posing. Teaching and Teacher Education, 25, 166-175.

Toluk-Ucar, Z. (2011). Öğretmen adaylarının pedagojik içerik bilgisi: öğretimsel açıklamalar. Turkish Journal of Computer and Mathematics Education, 2(2), 87-102.

Tuna, A., Biber, A. Ç., \& Yurt, N. (2013). Matematik Öğretmeni Adaylarının Matematiksel Modelleme Becerileri. Gazi Üniversitesi Gazi Eğitim Fakültesi Dergisi, 33(1), 129-146.

Van de Walle, J. A., Karp, K. S., \& Bay-Williams, J. M. (2004). Elementary and middle school mathematics. Boston: Allyn and Bacon.

Van Driel, J. H., Beijaard, D., \& Verloop, N. (2001). Professional development and reform in science education: The role of teachers' practical knowledge. Journal of Research in Science Teaching, 38, 137-158.

Van-Steenbrugge, H., Lesage, E., Valcke, M., \& Desoete, A. (2014). Preservice elementary school teachers' knowledge of fractions: A mirror of students' knowledge. Journal of Curriculum Studies, 46(1), 138-161.

Yıldırım, A., \& Şimşek, H. (2013). Sosyal Bilimlerde Nitel Araştırma Yöntemleri. Ankara: Seçkin Yayıncilık. 


\section{SUMMARY}

When there is a need for attention in teacher education, the concept of Pedagogical Content Knowledge (PCK), which has gained considerable importance and related studies is increasing day by day, is at the forefront. Shulman (1986) mentions three types of knowledge that must be found in a teacher. These are: (a) subject knowledge, (b) pedagogical content knowledge, and (c) curriculum knowledge. The PCK is defined by Shulman (1986) as the type of information that is most likely to have the strongest representations, representations, simulations, examples, and explanations necessary for a subject / concept to be understood by the individual. Besides, the knowledge of the factors that make it difficult and easy to teach some specific subjects or concepts is accepted in the PAP. Therefore, PCK seems to play an important role in understanding and eliminating the misconceptions of students.

The most abstract concept that students encounter in the primary education is the concept of fractions (Newstead ve Murray, 1998) and learning fractions is one of the biggest hurdles in students' learning mathematics (Behr vd., 1993). With regard to the fractions, it is seen that, while there are different studies in the field, the studies of candidate proposals examining PCK for the solution of possible misconceptions are very limited. From this point, the problem and sub problems of this research can be expressed as follows.

The problem statement of this study can be expressed as: How are the competencies of preservice teachers to use pedagogical content knowledge in the context of eliminating misconceptions about fractions concept, and are there significant differences / correlations among these competencies? In the study, the following sub problems were tried to be answered.

1. What are the methods that pre-service teachers use to eliminate misconceptions about fractions?

2. How do the methods used by pre-service teachers to eliminate misconceptions about fractions vary according to the type of misconceptions?

3. How are the competencies of pre-service teachers to eliminate misconceptions about fractions and how do they change according to the methods they used?

4. Are the competencies of pre-service teachers to eliminate misconceptions about fractions differ significantly according to the type of school graduated and have (or not) taken the Misconceptions in Mathematics Education (MiME) elective course?

5. Is there a meaningful relationship between pre-service teachers' competencies to eliminate misconceptions about fractions and general academic success of students (GASS)?

This research is a mixed method research and the design of the research was based on exploratory design. The study group is composed of 52 senior students who has been attending the Primary Mathematics Teaching program of a state university. Convenience sampling method as one of the purposive sampling methods was used in determining the study group.

In order to determine the pre-service teachers' competency of eliminating misconceptions, the researcher prepared the Form of Eliminating Misconceptions (FoEM). The form consists of two separate parts. In the first part, there are three questions about the demographic information of the teacher candidates. In the second part of the form, there are eight open-ended questions and each question contains different types of misconceptions about fractions. In these questions, pre-service teachers are asked what they can do to eliminate related misconceptions.

In accordance with the structure of the study, the data analysis process was carried out in four steps. These are; (a) creation of a scoring scale (SS) to be used in assessing responses to FoEM, (b) the coding and scoring of responses, (c) the carrying out of qualitative analyzes of the one, two and third subproblems of the study using the codes of the responses, (d) the use of the scores of the responses for the realization of quantitative analyzes for the fourth and fifth sub-problem of the research.

As a result of the research, it has been seen that the pre-service teachers usually prefer the methods of using models and make a statement / questioning in order to eliminate the misconceptions about the 
fractions. When the types of misconceptions are taken into consideration, it has been observed that preservice teachers prefer predominantly the method of using models in the categories of comparison of fractions, wrong fractional sum, multiplier effect on fractions and obtaining the half of the fractions and they use related method sufficiently. In addition, it has been seen that the pre-service teachers prefer the method of make a statement / questioning in general, in categories of separating parts, determining the unit in compound fractions, and division effect on fractions. In category of the amount depends on the whole reference, it has been seen that most of the pre-service teachers prefer to use the using concrete object / material method and use it in the correct way in general. Considering the quality of the answers of the pre-service teachers, it has been seen that nearly $37 \%$ of the pre-service teachers gave partially valid but inadequate answers. More explicitly, pre-service teachers have been able to express the correct method of eliminating the misconceptions of students, but they are inadequate in using this method. When the research results are examined for different question categories, it is seen that the question categories that pre-service teachers give inadequate answers are generally containing the operations with fractions and the meaning of fraction concept. In the study, it was seen that the quality of the answers did not show any significant difference according to the variables of the school type, GASS and being (or not) taken MiME elective course.

When it's considered that the first step of PCK is the undergraduate education process, it is suggested to improve the content of the mentioned programs in the context of the results obtained from this study. It is also possible that opportunities for pre-service teachers can be offered at the point of PCK improvement, with courses such as School Experience and Teaching Practice, where students have first gained experience in the teaching profession, are more involved in curricula. There seems to be very limited research on PCK in the field. It is suggested to carry out studies that deal with the teaching situations of different mathematical concepts. 